\title{
Celestinas y majas en la obra de Goya, Alenza y Lucas Velázquez
}

\author{
Rachel Schmidt \\ University of Calgary
}

A pesar de que se imprimieron pocas ediciones de la Celestina de Rojas en el siglo de las luces, como resume Joseph T. Snow, la fama de la obra "se incorporó en la conciencia del país» (2000: 46), hasta que la figura de su protagonista llegó a ser un tipo que designaba mujeres ejerciendo el oficio de terceras y alcahuetas. En el siglo XVIII se solía asociar la figura de celestina con una mujer madura y astuta que guiaba a un chico joven e inocente hacia un matrimonio, le conviniera o no. Es de esta manera como José Cadalso recomendaba al «militar a la violeta» la lectura de la obra de Rojas para que el joven ingenuo aprendiera a escaparse de los designios de las "viejas zurcidoras», herederas del oficio de la Celestina (Helman 1955: 221). Luis Paret y Alcázar, en su acuarela Celestina y los enamorados (1784), ya muestra el tipo de la anciana, con nariz bulbosa y mejillas hundidas, situada en un escenario empobrecido y circundada por botellas de vino (Snow 2000: 45). La tríada de celestina, prostituta y cliente será el modelo representativo de lo que Tomás Rodríguez Rubí clasificó como el rango más bajo de la «mujer del mundo», en un ensayo publicado en Los españoles pintados por sí mismos (1843); en este estudio, una viñeta con las cabezas de tres figuras, sirve como colofón al escrito (Figura 1). Los tipos son icónicos: la Celestina "con su nariz grotesca y su barbilla grande» dirige a la chica, situada en el centro, hacia el hombre, al que quiere vender sus servicios.

A fines del siglo xviII, Francisco de Goya y Lucientes fijó dos vertientes iconográficas en la representación de la prostituta: una primera, que era satírica en su enfoque, que vinculaba la temática celestinesca con el comercio sexual al igual que con el matrimonio forzado; y la segunda, que era más costumbrista y sentimentalista. La primera tendencia iconográfica la expresaba Goya a través del grabado (aguafuerte y aguatinta) y de los dibujos. La segunda la representaba en óleo sobre lienzo o con acuarela sobre marfil y/o alabastro. En ambas facetas, Goya empleó la moda dieciochesca del majismo para actualizar la temática celestinesca e incluirla en las disputas sobre la femineidad, las costumbres sexuales 
y la moralidad de su época. Fueron los llamados «seguidores de Goya» de la escuela madrileña los artistas decimonónicos que desarrollaron estas tendencias iconográficas. Carlos Reyero y Mireia Freixa distinguen el costumbrismo madrileño de los otros costumbrismos españoles por tener «una visión muy distinta de lo popular, mucho más amarga y desgarrada» (1999: 122), tendencia que explica, en parte, el que siguieran representando celestinas. Leonardo Alenza y Nieto (1807-45) partió de la vertiente satírica, pero sitúa su obra gráfica en las escenas callejeras verosímiles, de manera que introduce a los hombres en la iconografía. De este modo, la crítica social de Alenza llega a ser todavía más perspicaz, puesto que pone de relieve la relación social entre la prostituta y el vago. Eugenio Lucas Velázquez (1817-1870) optó por la vertiente pintoresca, tanto en la composición y temática de la maja cuanto en el uso del colorido y de la pincelada, que acentúa la sensualidad de las prostitutas. Dicho acercamiento sentimentalista, junto con el pincel ligero y proto-impresionista que Lucas Velázquez aplica a la temática celestinesca, desafina con la realidad del mundo de las prostitutas y madamas durante el reinado isabelino, ya que lo que se presenta es una visión costumbrista de los nuevos burdeles legalizados. Lucas Velázquez somete a la figura de la Celestina a un proceso de deshumanización que la transforma en monstruo o bestia, que corresponde a la demonización de la alcahueta propuesta por los escritores de la época.

\section{Goya, Alenza y la prostitución callejera}

Las imágenes de Goya que se pueden asociar más directamente con $\mathrm{La}$ Celestina de Fernando de Rojas son dibujos que pertenecen a su Álbum $\mathrm{D}$, de brujas y mujeres ancianas, que data aproximadamente de los años entre 1819-1823. ${ }^{1}$ España pasaba por un momento turbulento debido al conflicto entre Fernando VII y el Trienio Liberal; con la llegada de los llamados Cien Mil Hijos de San Luis y el establecimiento de la monarquía absoluta, Goya, al igual que muchos otros ilustrados y liberales, se exilió de España (Gudiol 1971: 1, 193-209). El artista se retiró a La Quinta del Sordo, donde vivió con Leocadia Zorrilla y se recuperó de la enfermedad enigmática que padeció en 1819 y que le dejó sordo. Allí se dedicó a las Pinturas Negras que adornaba la casa del campo. Como nota Juliet Wilson-Bareau del Álbum D, «The series as we know it con-

1.- Acerca de la discutida datación de este álbum, véase Wilson-Bareau 2001: 135. Las fechas que utilizo son las suyas. El hijo de Goya, a pesar de haber sacado dibujos de sus cuadernos originales después de la muerte de su padre, parece haber respetado la integridad de los álbumes y la secuencia original de los dibujos (Wilson-Bareau 2001: 20). Para conocer más sobre la historia de las subsiguientes ventas de los álbumes, véase Wilson-Bareau 2001: 24-5. El número 29 indica que Federico de Madrazo quería guardar ese dibujo en su colección particular. 
cludes...with a sequence of old women, two of whom totter on their sticks, while between them sits the indestructible Mother Celestina..., the indestructible bawd who is a constant presence in Goya's iconography» (2001: 19). Este dibujo, que corresponde al número 22 del álbum, lleva como título La madre Celestina, en el que se retrata a una mujer anciana pero fuerte, encapuchada, con un rosario en la mano derecha y una botella, se supone de una bebida alcohólica, en la otra (Figura 2). Como las mujeres ancianas de los Caprichos 17 y 31, a las que analizaremos más adelante, tiene hundidas las mejillas, característica que presuponemos como resultado de haber perdido los dientes, además de una nariz bulbosa. ${ }^{2}$ De acuerdo con Teresa Lorenzo de Márquez, en este dibujo, de aguada de tinta gris y negra, se evidencia que Goya conocía el texto de Rojas, puesto que incluye detalles pormenorizados tales como su vestimenta rota, la cicatriz en la cara, los frascos de perfumes y ungüentos reunidos con la ostentación hipócrita del rosario (Goya and the Spirit of the Enlightenment 1989: 300). La cinta que serpentea alrededor de la barriga junto con las piernas que estira de manera casi lasciva sirven, según Lorenzo de Márquez, para retratarla como un personaje dominado por las pasiones más ínfimas. De acuerdo con la matización hecha por Valeriano Bozal, este dibujo, al igual que los demás que proceden de este periodo de Goya, son grotescos y no satíricos, ya que la «sátira muestra lo inadecuado del comportamiento de las personas y, en este sentido, pretende conducirlas a un comportamiento adecuado, según normas o pautas que dependen de una naturaleza ejemplar, por todos aceptada como modelo" (2008: 408). Al contrario, aquí estamos ante una imagen grotesca, pues el efecto estético es «un 'hacernos' ver la deformidad en la que estamos» (2008: 411), que corresponde con lo que Bozal denomina "grotesco trágico» (2008: 415), típico de nuestra actualidad, pero que pudo corresponder igualmente al concepto de tragicomedia en Rojas.

Se han referenciado en la obra de Goya muchas imágenes que tienen relación con la iconografía celestinesca, si se la entiende como la tradición visual que representa la relación de una alcahueta con una prostituta. La prostitución había sido declarada ilegal en 1661 por Felipe IV; inmediatamente su práctica pasó a las calles y burdeles infames. El interés de Goya por la prostitución procede de varias fuentes: por un lado, no esquiva la mirada del aspecto pícaro de esas mujeres al mostrar la astucia, que fue motivo del retrato del oficio hecho por artistas anteriores, como Murillo o Paret; pero por otro lado, representa la violencia, incluso penal, dirigida a las mujeres prostituidas. Puelles Romero anota que la perspectiva de Goya sobre las prostitutas constituye un cambio en la his-

2.- Alcalá Flecha asevera que el Capricho 12, A caza de dientes, hace referencia directa al texto de Rojas (1984: 80). Sin embargo, representa a una mujer joven, en vez de una anciana, que roba un diente a un cadáver colgado. 
toria de su representación gráfica, pues es el primero que empieza a verlas como «reflejo» de la sociedad en que viven (114). Joseph T. Snow identifica dos dibujos de Goya que participan de la tradición celestinesca: Maja y Celestina bajo un arco, en el que la mujer anciana manipula las cuentas de un rosario, y No se levantará hasta que no acabe sus devociones (2000: 45). Alcalá Flecha ve referencias a Celestina en los siguientes Caprichos: 15, Bellos consejos (1984: 82) y 17, Bien tirada está (1984: 86). ${ }^{3}$ También considera que son celestinescas algunas imágenes de naturaleza alegórica, caso del Capricho 19, Todos caerán (Alcalá Flecha 1984: 108), en el que se incluye una figura con reminiscencias a una anciana celestinesca. En un manuscrito de la Biblioteca Nacional, que contiene un comentario contemporáneo de Goya, aclara el significado del pájaro desplumado, puesto que «desplumar» en la jerga callejera quería decir robar: "Una puta se pone de señuelo en la ventana, acuden militares, paisanos y hasta frailes y toda especie de avechuchos revoloteando alrededor; la alcahueta pide a Dios que caigan, y las otras putas los despluman, y hacen vomitar, y les arrancan hasta las tripas como los cazadores a los perdices» (Alcalá Flecha 1984: 110). El Capricho 20 lo resalta: Ya van desplumados (Alcalá Flecha 1984: 116). El significado del Capricho 35, Le descañona, depende igualmente de un juego de palabras, ya que «descañonar» también quiere decir robar a través del engaño (Alcalá Flecha 1984: 116). El Capricho 21, ¡Cuál la descañonan!, presenta el chiste visual del ave desplumada junto con el acto de afeitar a alguien, pero esta vez haciendo referencia a las formas en que el sistema judiciario maltrata a la prostituta. Como se lee en el comentario de la Biblioteca Nacional, «Los jueces superiores hacen capa regularmente a los jueces superiores y alguaciles para que roben y desplumen a las putas pobres» (Alcalá Flecha 1984: 121).

Claves para establecer la vertiente iconográfica satírica o crítica de Goya son los Caprichos 31 y 17. Edith Helman encuentra en el Capricho 31 de Goya, Ruega por ella, una alusión visual al modelo de Celestina, ya que el rosario, desde tiempos de Boccaccio, es atributo del oficio de la alcahueta (1955: 227) (Figura 3). Es más, Helman señala el doble significado del verbo rogar, palabra que denota a la vez orar y pedir. La visión crítica de Goya que se presenta en este grabado abarca la explotación de la muchacha, guiada como presa hacia la prostitución o el matrimonio. El Capricho 31 pertenece a una de las temáticas que Goya desarrollará a lo largo de su vida: la de la maja y la celestina; se destaca en el centro de la imagen una chica joven y guapa que está iluminada mediante un efecto blanquecino y expuesta a la mirada del espectador. Ella no esquiva la mirada; al contrario, la chica la devuelve de manera abierta, si no coqueta, mientras

3.- Alcalá Flecha incluye 36, Mala noche, en la lista de obras goyescas que tratan de temas celestinescos, a pesar de que no incluye la figura de una anciana, porque trata de la prostitución callejera (1984: 103). 
Celestina «ruega» mientras contempla la pierna desnuda de la maja, y otra chica, colocada detrás de ella, peina su largo cabello. Asimismo el Capricho 17, que ostenta el rótulo Bien tirada está, presenta a una anciana revisando con mirada astuta la pierna desnuda de otra maja.4

La prostitución, tal como Goya la representa, está estrechamente vinculada con la religión y el matrimonio, junto con el mundo de la delincuencia. Es cierto que el rosario sirve como seña de identidad de Celestina, pero la relación entre prostitución y religión en el contexto dieciochesco y decimonónico va más allá de la mera hipocresía, atributo de la alcahueta protagonista de la obra de Rojas. Eleanor A. Sayre observa que en el Álbum D, donde aparece el dibujo titulado por el artista La madre Celestina, Goya incluye también a monjes y frailes de manera crítica y grotesca: un monje que ronca y una procesión de frailes que cantan mientras salen borrachos de una capilla (Goya and the Spirit of the Enlightenment 1989: cxv). Las prostitutas tenían una relación complicada con la Iglesia, pues practicaban su comercio a las sombras de sus edificios y durante sus solemnidades. Grupos de mujeres "faltas de religión», según un informe oficial de 1800, entraban en las procesiones de Corpus Christi cantando romances indecentes y, se supone, en busca de clientela; esta costumbre llegó a causar tantos disturbios, hasta peleas entre los hombres, que en 1815 se prohibió que las mujeres asistiesen a las procesiones de Semana Santa (Tomlinson 1992: 173-4). Estas prostitutas pertenecían a burdeles que se llamaban, en jerga popular, "conventículos»y, tras ser detenidas por ejercer su oficio, eran ingresadas en casas de "magdalenas», de las que solo podían salir para entrar en un convento o para casarse (Harrison 1986: 57-9). Las alcahuetas reclutaban a nuevas chicas en las iglesias, a la vez que a los clientes masculinos entre los clérigos (Salas García y Sánchez Hita 2000: 73, 79). Eugenio Lucas Velázquez representa las relaciones íntimas entre la clerecía y la prostitución en su óleo sobre lienzo de índole anticlerical, Majas y frailes en una bodega (hacia 1850-1870). Trabajar para una celestina ofrecía a la prostituta protección y acceso a una clientela más adinerada; pero las alcahuetas sólo aceptaban mujeres de buena salud, tal como se representan las celestinas escudriñadoras de los Caprichos, que evalúan a los cuerpos de las chicas buscando indicios de buena o mala salud (Salas García y Sánchez Hita 2000: 74).

El comercio de carne femenina se extiende al matrimonio forzado bajo la óptica satírica de Goya, pues las terceras emplean el mismo doble juego de «rogar»y «pedir» en sus negocios. Dos mujeres, con la misma fisionomía facial celestinesca, protagonizan uno de los Caprichos vinculados al tema matrimonial: el número 2 , El sí pronuncian y la mano alargan

4.- López Vázquez: 2009, identifica este grabado, Capricho 17, como el culminante de una pequeña serie - 15, 16 y 17- que trata de la temática celestinesca como emblema de males mayores: el Engaño figurado por la joven y la Mentira figurada por la anciana. 
al primero que llega (Figura 4). Una de ellas, con las palmas de las manos juntas como si estuviera rogando, lleva a una doncella, con los ojos vendados, hacia un matrimonio forzado. El público que grita y se burla de ella, no deja lugar a dudas acerca del crítico significado del título de la imagen; tampoco pasan por alto la reprimenda social de los muchos comentaristas de la época que tomaban a la chica como princesa o camarista. ${ }^{5}$ La temática del matrimonio a ciegas y sus consecuencias obvias es un leitmotiv en la obra de Goya, pues recurre a ella en el Capricho 14, ¡Qué sacrificio!, en el que un enano jorobado se casa con una joven. Asimismo, Goya se interesa por qué es lo que mantiene unidos estos matrimonios. Susan Watts (2007: 25-6) percibe que hay semejanzas tanto de tema como de composición entre el Capricho 75, No hay quien nos desate (Figura 5), y Disparate matrimonial (1815-19) (Figura 6). El comentarista del manuscrito del Prado interpreta el Capricho como una clara referencia al yugo matrimonial, ya que el hombre tiene sujeta a la mujer por una cinta que le circunda la cintura, mientras un búho se posa sobre ella. En el Disparate, un medio cuerpo grotesco de hombre mantiene a la otra mitad de una mujer ante unos seres extraños que los miran: un pájaro, gatos y seres humanos. Estas mujeres ya no están sujetas por el engaño, sino por la fuerza del matrimonio, visto éste como disparate.

Ante el incremento de la prostitución callejera en los siglos XVIII y XIX, la policía reaccionó de acuerdo con el mismo modelo de control que se había decretado ya en la recopilación de leyes de 1661: detener y encarcelar a las prostitutas (Guereña 2008: 219). Dicha práctica policial la plasma Goya en dibujos y Caprichos. El dibujo del Álbum F, número 86 (1812-23) representa un episodio histórico en el que unos estudiantes y prostitutas atacaron a un tal alguacil Lampiños con cal viva (Alcalá Flecha 1984: 124-26). Capricho 22, ;Pobrecitas! parece representar a dos prostitutas callejeras que son detenidas por fuerzas de seguridad (Alcalá Flecha 1984: 127), junto con el dibujo de Álbum B (1796-97), número 82, titulado Pobres, ¡cuántas lo merecerán mejor!, ¿pues qué es esto?, que ha de ser, que las llevan a San Fernando, que representa una escena semejante (Alcalá Flecha 1984: 127-9). El Correccional de San Fernando formaba parte de la red de hospicios amparados por el gobierno como parte de la reforma ilustrada que tuvo lugar con Carlos III. Se reemplazaron los antiguos hospitales y asilos

5.- El comentario de Ayala se lee así: «Reprende los matrimonios a ciegas, como los de las princesas y camaristas»; el de Stirling: "Reprende los matrimonios a ciegas de los Principes: una figura lleva manto real; la otra como una corona, y un inmenso pueblo necio aprueba y aplaude el enlaze. Hai que observar una especie de cara de mona que forma el colodrillo de la novia. Bodas de las Camaristas»; el de Simon: "Los matrimonios se hacen regularmente a ciegas: las novias, adiestradas por sus padres, se enmascaran, y atabian lindamente, para engañar al primero que llega: esta es una princesa con mascara, que luego ha de ser una fiera con sus vasallos; como lo indica el reverso de su cara, imitando un peinado: el pueblo necio aplaude estos enlazes: $y$ detrás viene orando un embustero en trage sacerdotal por la felicidad de la nación" (Goya and the Spirit of the Enlightenment 1989: 86-7). 
para necesitados, patrocinados por hermandades y otras asociaciones de tipo religioso, con el fin de educar y enseñar a los «verdaderos» pobres y necesitados un oficio, para incorporarles como individuos productivos en la economía española (Ramos Vázquez 2009: 253-4). El Capricho 34, Las rinde el sueño, muestra a dos prostitutas que están encarceladas junto a sus celestinas (Alcalá Flecha 1984: 135). Otro dibujo del Álbum B, número 84, San Fernando, ¡Como hilan!, representa a tres prostitutas que trabajan en el Correccional de San Fernando, donde están encerradas para su rehabilitación (Alcalá Flecha 1984: 139). Las leyendas y la representación de episodios históricos en los dibujos de Goya revelan una simpatía durante toda su vida hacia aquellas mujeres que no tenían otra opción que la de vivir así. Es de destacar que el Álbum D, que contiene el dibujo La vieja Celestina, y el Álbum F estén fechados en el momento en que el número de prostitutas aumentó durante la guerra napoleónica y el subsiguiente debate político que ocurrió sobre una posible reforma de las leyes concernientes a la prostitución durante el Trienio Liberal de 1820-23.

La invasión napoleónica y la guerra de independencia introdujeron desorden social y económico, además de nuevas costumbres. Un documento legal dictado en Madrid en 1815 atribuye el alto número de mujeres que vivían de la prostitución a la separación forzada que muchas de ellas sufrían de sus maridos, padres y hermanos (Guereña 2008: 220). Durante la ocupación francesa, en locales de Valladolid, se adoptó la tolerancia francesa hacia la prostitución, tal vez para acomodar a las tropas galas, pero también para proteger a las mujeres comerciadas; al no ser aceptadas de nuevo por la comunidad, ellas serán las víctimas de actos de violencia al estar deshonradas (Guereña 2008: 221). Además, quedaron en España muchas mujeres que acompañaban a los soldados británicos y franceses y que fueron abandonadas una vez partidos los ejércitos; se ha estimado que la salida de las tropas inglesas trajo el abandono de unas 4.500 mujeres (Esdaile 2014: 71). También se introdujo el uso de preservativos; eso no impidió que la tasa de enfermedades venéreas aumentase, sembrando el miedo en la sociedad (Guereña 2008: 222). Fue entonces, durante el Trienio Liberal, cuando un comité llegó a proponer un registro de todas las «mujeres públicas» para proteger la higiene ciudadana, que incluiría un examen médico semanal (Guereña 2008: 225). Dichas propuestas fueron promulgadas como ley justo después de la muerte de Alenza en 1845.

La perspectiva de Leonardo Alenza sobre la temática celestinesca parte de la tendencia crítica de los dibujos y grabados de Goya. El parecido entre los dibujos de Alenza y la expresión gráfica de Goya en sus estampas, por ejemplo, impulsó a Isidoro Rosell y Torres a grabar en aguafuerte los dibujos de Alenza, que publicó como una colección de "Caprichos» en 1877, 32 años después de su muerte. Tras su adquisición por el librero Mariano Murillo, el álbum fue reeditado en Londres en 1895 con la siguiente anotación: «Número de orden, 2.280; Alenza (Leonardo): Caprichos originales, 
continuación de los de F. Goya. -30 dibujos originales de bellísimo estilo goyesco. Época, 1850» (Palencia Tubau sf: 9). ${ }^{6}$ Basándose en las estampas ejecutadas por Rosell e impresas en 1877, Palencia Tubau observa que les faltan a los aguafuertes el "vigor indomable» y la "arrolladora energía» de Goya: «desenvueltas manolas y vetustas celestinas a caza de incautos, y alguna que otra vez tal cual licencia política, son los mayores atrevimientos a que Alenza llega. ¿Por qué tal temor o cortedad?» (sf: 10). Pero el juicio de Palencia Tubau no alcanza a apreciar a Alenza dentro de su propio contexto creativo, ya que su visión se distingue de la de Goya por la observación, que le permite ver fenómenos cotidianos, que por el mero hecho de ser cotidianos pasan a ser invisibles. Así describe certeramente Ginger (2007: 220) el talento de Alenza, como una capacidad de acercarse con ambigüedad matizada e inexpresiva hacia las actividades de las clases bajas. Una gran parte de la obra de Alenza consta de dibujos que fueron grabados en madera por especialistas, como Castillo, e impresos en las Escenas matritenses y el Semanario Pintoresco Español, ambos editados por el periodista y reformista Mesonero Romanos, cuyo fin fue, en palabras suyas, "crear impresiones del momento" y presentar al lector artículos que ofrecieran algo diferente a la novela, por no entrar "ya en los profundos y enmarañados bosques de la ciencia política, no en el animado cuadro de la historia contemporánea, sino en el menos armónico y consecuente de los usos y costumbres populares» (Ginger 2007: 114). Se ve este interés por lo actual en el siguiente dibujo, en donde lo clásico y típico se mezcla entre los rincones de Madrid. En el Semanario Pintoresco Español se publicó una ilustración con la leyenda "Culto de Venus», que representa a una celestina decimonónica, diseñada por Alenza y grabada por Castillo. Está de pie en la puerta, mirando hacia dos jóvenes que pasan por la calle, mientras dos chicas se asoman a las rejas de la ventana. Dicha imagen va pareja con otra que lleva el rótulo "Culto de Baco", y que representa a unos bebedores en una taberna de Lavapiés o Barquillo, pues ambos constituyen «Peligros de Madrid» (Rubio Cremades 2012: 872).

Si la visión de Alenza es crítica con aquellos que vivían de la prostitución, no lo es por presentarla de manera grotesca o monstruosa. Un aspecto capital de sus obras, que todavía lindan con el costumbrismo, ha sido el de abrir la perspectiva de la temática celestinesca al incluir dicho fenómeno dentro de su marco social. Al adoptar una postura de observador, tal vez neutral, Alenza abre el panorama del plano pictórico para incluir elementos que habían sido excluidos en representaciones anteriores, pero que sí revelan aspectos llamativos del comercio sexual. En el cuadro al óleo Joven y Celestina, en el que una prostituta se asoma detrás

6.- Torres González distingue entre el enfoque de los Caprichos de Goya y los de Alenza, insistiendo en que en los de Alenza falta la crítica social que se ve en los Caprichos satíricos de Goya (1997: 18). Sin embargo, a mi parecer, en cuanto se trata de la temática celestinesca, Alenza comparte este deseo de denunciar la participación masculina en el mundo de la prostitución. 
de la cortina - que oculta una alcoba - para tomar una jofaina, Celestina ocupa el centro de la sala principal. ${ }^{7}$ Está moviendo la rueda de una rueca con el pie, y tiene en la mano hebras de hilo verde. De hecho, en tiempos de Alenza, muy poco separaba de la prostitución a las mujeres que trabajaban en las industrias asociadas con la costura y la fábrica de textiles, pues si no fuera por la cantidad mínima que cobraban de costureras, hilanderas o calceteras, se encontrarían ejerciendo el oficio de prostitutas o estarían confinadas en el Correcional de San Fernando (Haidt 120). En la silla de al lado está el yelmo del caballero y su espada se balanza entre la silla y la rueda, una alusión irónica y visual del encuentro sexual que tendrá lugar en la otra habitación, enfatizado por las siluetas de la rueda y la espada. A pesar del ambiente tranquilo, la ausencia física del caballero se hace presente no sólo de forma simbólica sino también económica, pues el poder del dinero y de la clase del hombre se destaca a través de su armamento. En otro cuadro al óleo, Joven en el balcón, una muchacha se asoma al balcón de una casa mientras la celestina se asoma detrás de ella. Apenas se percibe una tercera cara detrás de la joven. La fachada del viejo edificio revela la estructura de ladrillos, por lo que no queda duda de que la pobreza da ímpetu al comercio sexual. La paleta de pardo y castaño claro se pone en relieve solo con los toques de amarillo y rosado en la vestimenta de la maja y el azul del cielo, lo que resulta en un ambiente es opresivo. En el cuadro de Alenza, La maja del balcón (c. 1840) que pertenece al Museo de Bellas Artes de Bilbao (Figura 7), se ve a la celestina con aspecto lúgubre, casi en forma de calavera, que se incluye dentro de la tradición de memento mori, que ha sido destacada por Enrique Fernández como un eje organizador de la recepción gráfica de La Celestina («The Images of Celestina»). El enfoque del cuadro es más tradicional, ya que el plano pictórico se reduce al balcón mismo. Una gran cortina sencilla, de color castaño claro, domina la parte derecha, formando un bulto sustancial contra el que la sombra de la maja se proyecta. El artista ha querido prestar en este caso más atención a la vestimenta y los adornos de la maja, pues la falda se destaca en tonalidades de rosado, la mantilla negra revela una flor que ornamenta su tocado, y los brazaletes dorados embellecen sus brazos corpulentos. A pesar de la robustez de la muchacha, su rostro tiene aspecto de muñeca, al llevar colorete en las mejillas y una ceja arqueada, que fija la mirada en algo que está situado debajo del balcón. El aspecto mecánico de su vista se aumenta, ya que el tamaño de cabeza, relativo a su cuerpo es demasiado pequeño. Todo ello le da al cuadro un

7.- Joven y Celestina se vendió en 1999. Sobre el cuadro Joven en el balcón no tengo datos fehacientes, tan solo que salió a subasta. Torres González identifica otros dibujos de Alenza, que pertenecen al Museo del Romanticismo Nacional, ubicado en Madrid, que versan sobre la temática de la prostitución y la figura de Celestina: D.7 Bailadora y brujas, D. 6 Clamando al cielo, D.22 Mendigas y D. 11 Moza al balcón y cómico ambulante, además de dos láminas de los Caprichos, E. 6 y E. 18 (1997: 31). 
efecto siniestro, lo cual enfatiza el poder de la celestina detrás de la maja. El control de la celestina se destaca más en otro cuadro del mismo tema que pertenece al Museo de Bellas Artes de Budapest, pues allí la celestina, identificada por su nariz prominente y pelo gris, ocupa el centro del plano pictórico, aunque está en las sombras, y gesticula mientras le susurra algo a la maja sentada a la derecha, que tiene aspecto melancólico. La maja mira con desgana hacia el espacio del espectador, mientras escucha los consejos de la celestina. En la parte izquierda del cuadro, Alenza pinta a una chica que se vuelve hacia el espectador, revelando así el rico atuendo blanco de maja, pero que sirve, igual que la cortina de la derecha, para limitar el espacio accesible a la vista. De nuevo, el efecto es el de enfocar la mirada del espectador en el gesto de la alcahueta y los ojos melancólicos de la maja.

Cuando uno ve los dibujos de Alenza, es obvio que éste se atrevió a tratar de una relación de las celestinas que no fue representada por Goya. A diferencia de Goya, Alenza a veces retrata a la Celestina en interacción con hombres pobres, en vez de mujeres. Alenza, en su obra gráfica, agrupa a la figura de la alcahueta con hombres marginados, los vagos y ociosos, introduciendo una nueva constelación iconográfica a la temática celestinesca que responde a la actualidad decimonónica. En una aguada con toques de tinta bugalla con título Esperando en el balcón, que pertenece al Museo Lázaro Galdiano (INV 10089 c. 1835), se ve un balcón desde el interior (Figura 8). Esta inversión de la representación típica de la escena de las majas al balcón permite la visión de los hombres, ya que sin su presencia el comercio sexual no existiría. Además de la maja que mira a la calle y la celestina que se asoma por la cortina, en el cuarto hay dos hombres que visten con capas oscuras de color indeterminado: uno que viste gorra y está de pie en la sombra, y otro que está sentado en el suelo con las piernas echadas hacia delante y la cabeza hundida en el pecho, como si estuviera dormitando. La identidad encubierta de ambos hombres indica la naturaleza clandestina del encuentro, mientras que la postura dormida y postrada de uno de ellos apunta a que lo contemplamos en un lugar en donde no se observan las normas de conducta pública. La Celestina en esta imagen se reduce a una figura pequeña sentada en el suelo; se esconde detrás de la cortina, y que da la espalda al espectador, pero es ella la única figura que se presenta de acuerdo con las costumbres de la época. Mira y gesticula hacia el exterior, tal vez apalabrando el próximo cliente y ocupando, en términos sociológicos, la puesta en escena hacia el público de la calle (Goffman 1963: 125-8). En contraposición la maja, que se reclina contra la reja del balcón y mira hacia un horizonte distante. La chica, que reposa una mano sobre el hierro de la barandilla, recoge la tela rosada de su mantilla con la otra, en un gesto que destaca su estado anímico de ensueño. El color verde de las mangas sirve para llamar la atención a este gesto mínimo pero significativo, porque la mano en el pecho separa 
a la muchacha del espacio interior de la habitación, mientras que la otra, estirada y abierta hacia el exterior, al igual que su mirada, la transporta hacia otro mundo. La sombra de la cortina cae sobre sus ojos, ocultando todavía más su mundo interior al espectador. Esta maja, a diferencia de la típica que se presenta en la iconografía, no se muestra al público, sino que se encierra en su propia interioridad. Contraviniendo otra convención de la escena de majas en el balcón, Alenza representa a un gato en su regazo que dirige la mirada al espectador. Al reorientar la posición de la escena vis-a-vis al espectador, el artista muestra ls bambalinas del comercio sexual, lo que sería, en términos del sociólogo Erving Goffman, el espacio detrás de los bastidores. Este espacio se presenta en tonalidades de gris y pardo, como espacio vacío de adornos y de expectativas. Es más, el momento temporal que Alenza escenifica es el de transición entre un cliente y el siguiente, cuando los hombres muestran el cansancio detrás del encuentro, la maja sueña estar en otro lugar más idílico, y la alcahueta busca un nuevo beneficio.

Alenza representa a las alcahuetas con hombres pobres, mendigos y prostitutas. Ya desde el siglo xviII se habían promulgado leyes y pragmáticas civiles que agrupaban a las prostitutas con los «vagos» $y$ "Ociosos», puesto que se entendía que las mujeres sin formación ni educación no tenían otra salida económica más que la de entrar en la prostitución (Guereña 2008: 227-8). De hecho, las leyes del siglo xviII que crearon nuevas reglas e instituciones para registrar y reformar la muchedumbre indigente identificaban a los «vagos», "ociosos» $\mathrm{y}$ "mal entendidos» con todo tipo de personas, incluso mujeres públicas, hombres venidos del campo en busca de trabajo, mendigos, discapacitados (denominados "vagos ineptos»), titiriteros, jugadores y delincuentes (Ramos Vázquez 2009: 248-9). La Celestina se ve de forma similar por su capacidad de traficar y/o comerciar, como así aparece en el dibujo Vieja Celestina, que pertenece a la Biblioteca Nacional de España, en donde ésta se inclina sobre un joven sentado que mira al espectador. ${ }^{8}$ Él está descalzo y muestra el pecho y las piernas desnudos, mientras se da la vuelta para mirar, con aspecto levemente perturbado, hacia la alcahueta. Es posible que exista aquí un indicio de prostitución masculina, tema que Goya no se atrevió a representar tan abiertamente. Modificando la iconografía celestinesca, es un joven en vez de una muchacha el que se expone, con el mismo aspecto de objeto sexual que encontramos en las imágenes goyescas de prostitutas femeninas exhibidas por alcahuetas. En otro dibujo de aguada de tinta parda, con el título Pobre y Celestina (Figura 9), el hombre pobre, esta vez vestido de cuerpo entero, aunque con capa rota, se presenta ante el espectador con mano en pecho y gorra en la otra mano, de manera que parece mendigar, mientras que la celestina lo observa o lo vigila por de- 
trás. ${ }^{9}$ Llevar capa a mediados de siglo Xvill se asociaba con personas de estatus bajo e incluso vagamundos, pues, como nota Haidt, la capa tenía variedad de funciones: como manta para protegerse del frío; para encubrir la falta de ropa de moda, limpia o en buen estado general; para ocultar tareas ilícitas, tales como llevar contrabando o robar; o para encubrir intenciones sexuales y seducir (Haidt 2011: 125). Es por eso que en 1751 se prohibió que accediesen a la Sala de Alcaldes de Casa y Corte aquellos que llevaban capa, convocando las tropas para impedir su entrada en al área del Prado (123). A veces Alenza sitúa la temática de la prostituta y la celestina en un escenario menos lúgubre, pero más cotidiano, donde solo se insinúa el comercio sexual (Museo del Romanticismo 2011: 303). En la Escena campestre (Figura 10), aguafuerte y aguatinta hecha en 1877 en base a un dibujo de Alenza, se ve que la figura de la alcahueta, esta vez una mujer anciana, pero menos grotesca, se presenta sentada con la cabeza descubierta, colocada al lado de la maja sentada debajo de un árbol, mientras dos mujeres hablan con hombres cubiertos y encapuchados. La maja esquiva la mirada del grupo de los hombres que la admiran con interés adquisitivo, y es de nuevo la celestina la que interactúa con ellos para gestionar la transacción. Es cierto que en este dibujo hay rasgos grotescos que Alenza atribuye, esta vez, a las caras de los hombres, pues el encapuchado de en medio tiene una nariz muy chata y las facciones de la cara del hombre de la derecha apenas se distinguen. La más grotesca es la del hombre que está apartado a la izquierda, que el artista delinea con pocos trazos y una cara de sonrisa y nariz simiescas.

En estas tres imágenes, la relación entre la figura de la celestina y los hombres es la que el artista pretende acentuar. En el caso de los pobres, están sujetos a su estado de marginación social y al poder de la alcahueta, pues es ella la que les controla el espacio mínimo donde comerciar lo único que pueden vender: en el caso del joven, su cuerpo a cambio de un momento de placer corporal que recibirá el consorte sexual; y en el caso del mayor, su aspecto mísero a cambio de un momento de placer espiritual que recibirá el que le da limosna. La destreza expresiva de Alenza al crear esos espacios marginales se encuentra en su minimalismo, pues construye un primer plano donde el hombre se acerca al espectador, plenamente situado en el espacio del comprador, y un segundo plano ocupado por la celestina. La abyección que experimentan los pobres en estos dos dibujos es una extensión, tanto de su relación espacial con el espectador, a quien extienden, bien su mirada de suplicación en el caso del mendigo, bien su cuerpo desnudo en el caso del joven, cuanto de su dependencia con la celestina colocada detrás de ellos. Están, desde luego, en la misma situación que ocupan las majas prostitutas representadas en las obras de Goya. Dicha colaboración con el tráfico de seres humanos,

9.- Este dibujo se ofreció en venta en un lote de Subastas Segre en 2013. 
y la subsiguiente vergüenza que la complicidad conlleva, explica que los hombres de la Escena campestre lleguen encapuchados. Al haber participado en la incipiente prensa burguesa, mucha de ella destinada a un público compuesto por mujeres de familias acomodadas, Alenza crea imágenes de la prostitución para un auditorio en el que los hombres que compran los servicios de prostitutas aparezcan denigrados. ${ }^{10}$ En el número 85 (11 de diciembre 1837) del Semanario Pintoresco Español, un periodista que escribe bajo el seudónimo de "El curioso parlante» describe en «Madrid a la luna» una noche que pasa acompañando a "un sereno", que se supone que es un buen padre de familia. Entre los episodios de la noche, se relata un encuentro con un señorito que susurra en «la sola calle en el cuartel» - a la que el sereno no entra - hasta que el narrador, guiado por la curiosidad, encuentra «un apuesto galán embozado hasta las cejas, y tan profundamente distraído en sabrosa plática con un bulto, que no echó de ver nuestra llegada, hasta que ya inmediatos a él, Alfonso tosió varias veces» (Semanario pintoresco 1837: 355). El narrador sabe nadar entre dos aguas, pues, respetando a la lectora burguesa, no menciona el comercio sexual sino mediante perífrasis: «el bulto blanco desapareció, y la misteriosa capa, también» (356). No obstante, da guiños al lector masculino: «Al llegar aquí no pude menos de respetar en Alonso el Dios tutelar de aquel misterio, y comparando esta escena con la anterior [de una mujer que pedía extremaunción por un familiar], eché de ver que entre la vida y la muerte todavía hay en este mundo alguna cosa interesante y placentera».

\section{Goya, Lucas Velázquez, el Majismo y la prostitución de burdel}

A diferencia de Alenza, Eugenio Lucas Velázquez desarrolla la segunda vertiente iconográfica de la celestinesca establecida por Goya, la que tiende hacia el sentimentalismo en la temática y el sensualismo en la estética además de la representación del fenómeno social del majismo. Hay otra visión más pintoresca de la temática celestinesca en algunas imágenes de Goya, la que se ve en Maja y celestina al balcón, el cuadro al óleo (1808-12) (Figura 11) y Celestina maja (Figura 12), carboncillo y acuarela en marfil (1824-5). ${ }^{11}$ En el lienzo al óleo, las dos mujeres dirigen la mirada directamente al espectador, postura solicitante típica del oficio de alcahueta y de la prostituta, pero que también remonta a la tradición iconográfica vista, por ejemplo, en algunas obras de Bartolomé Esteban Murillo. Angulo Î́niguez observa que Murillo, en su cuadro Hijo pródigo expulsado por

10.- Se ha descrito al lector ideal del Semanario Pintoresco Español como «la dama casada, de buena posición, en un contexto urbano» (Palomo 2012: 938).

11.- El famoso Majas en el balcón, cuadro en el que aparecen dos majas sentadas y dos hombres cuyas caras se esconden con capas detrás de ellas, en la actualidad se duda que fuera de la mano de Goya (Goya. Images of Women 2002: 246-9). 
las cortesanas (hacia 1660), ya había colocado "tras el matón el perfil de vieja descarnada, de nariz y barbilla prominentes, de la Celestina, que, sin embargo, no aparece en la estampa inspiradora [de la composición] de Callot» (1979: 211). Haciendo referencia a refranes tales como «mujer ventanera, uvas de carrera", el historiador de arte sugiere que hay relación con el tema celestinesco de prostituta y alcahueta en el cuadro famoso de Murillo de la misma época, Mujeres en la ventana (Figura 13), cuadro que estaba en posesión del Duque de Almodóvar, consejero de la Academia de San Fernando, el cual fue conocido por Goya (1979: 211-2). ${ }^{12}$ En el cuadro Maja y Celestina al balcón de Goya, la Celestina se reconoce por el rosario que lleva, pero la chica, a pesar de exponer el pecho, muestra una sonrisa melancólica, que para Margarita Moreno de las Heras sugiere la metáfora del pájaro enjaulado (Goya and the Spirit of the Enlightenment 1989: 160). ${ }^{13} \mathrm{La}$ acuarela en marfil representa a la maja que esquiva la mirada hacia la izquierda del plano pictórico a la vez que sostiene la mejilla en la mano. El desapego de su mirada junto con su postura desdicen la liviandad que anuncia: la ropa diáfana que deja ver sus pechos, junto con su mantilla y abanico, instrumentos todos ellos de su oficio de prostituta. La Celestina también evidencia una mirada menos directa, tal vez efecto de las dimensiones mínimas de la obra $(5.4 \times 5.4 \mathrm{~cm})$. Se ha conocido recientemente otra pintura de pequeño formato atribuida a Goya, Maja y Celestina pintada sobre alabastro con aguada de color monocromo de tinta negra y que pertenece a la colección de D. Asisclo Fernández Vallín. En esta imagen ambas mujeres están sentadas en un escenario doméstico humilde. La Celestina, barbilla sostenida por la mano que está sobre la rodilla, mira atentamente hacia la chica. De la misma mano cuelga una faltriquera, detalle que diferencia esta imagen de las demás, donde el bolsillo reemplaza el típico rosario (Rodríguez Simón 147). Lo que se destaca en esos cuadros, por su uso de color y por el medio, son los efectos pin-

12.- El cuadro estaba en Madrid hasta que fue vendido en 1823; si Goya no lo conoció en persona, se habría percatado de su reproducción en forma de estampa por J. Ballester (Angulo Íniguez 1979: 212).

13.- De acuerdo con Angulo Íñiguez, Cantón ya considera que el cuadro es de temática celestinesca (1979: 211). En la actualidad pertenece a una colección privada. Debido a la radiografía de los lienzos y al análisis del inventario de bienes de la mujer de Goya, Josefa Bayeu, se sabe que la Maja y Celestina al balcón forma parte de una serie de tres cuadros hechos entre 1810 y 1812, pintados éstos sobre un lienzo del siglo xviI basado en un grabado alegórico de Adriaen Collaert sobre los cuatro elementos. Estos tres cuadros de Goya incluyen el Lazarillo de Tormes, Las viejas y El tiempo (Goya. Un regard libre 1998: 230-8). El segundo cuadro tiene referencias al memento mori, con el espejo que lleva el letrero Qué tal?, además del envejecimiento de la figura rubia de la maja vestida de blanco. La otra maja, que lleva mantilla negra, tiene la cara típica de Celestina, pero con los ojos hundidos y la carne que está en proceso de descomposición típico de una calavera. Sin embargo. Goya puso mucho detalle a la pintura del vestido blanco de la vieja, que se describe como "un véritable morceau de peinture pure» (1998: 240). En cuanto a la temática de una mujer anciana que se acicala ante un espejo, hay un vínculo directo con el Capricho 55, Hasta la muerte (1998: 241). 
torescos y la ausencia de la acerba crítica de la práctica social de la prostitución, presente en los grabados públicos y dibujos privados de Goya.

Aunque Goya viste a sus prostitutas de majas en los Caprichos y Dibujos, los aspectos sensoriales de la moda sobresalen más en las pinturas y sobrepasan los aspectos críticos que pudieran expresar las imágenes. El majismo fue la costumbre de usar una vestimenta que procedía de las clases bajas, incluso gitanas, de Andalucía, y que fue adoptada por las clases obreras a finales del siglo XVIII (Ribeiro 2002: 78-85). Las prendas fundamentales de esta moda eran la mantilla (en negro o blanco), la basquiña (una falda corta que se llevaba sobre la falda larga) y el abanico. Ya a mediados del siglo xviii se aceptó la moda de las majas entre las mujeres de clase alta, de tal manera que en una colección de estampas de 1777, Colección de trajes de España, grabados a mano por Juan de la Cruz, los retratos de clase alta Petimetra con manto en la Semana Santa y la Maja elegante, llevan el mismísimo atuendo: basquiña, mantilla, abanico y peinado recogido mediante una cofia. ${ }^{14}$ La definición de petimetra parece que fue bastante dúctil, pues de acuerdo con su uso en el teatro del siglo XVIII se refería no solo a las mujeres adineradas sino también a las que buscaban no trabajar a través del engaño (Haidt 2011: 231). De todos modos, las majas y las petimetras representaban en el imaginario social dos extremos opuestos, excepto en cuanto a la ropa y adornos que llevaban. Como nota Molina, "tan solo las distinguen las joyas de la petimetra en forma de pendientes, collar, brazaletes, dijes y hebillas del zapato, así como la calidad de los finos encajes de su mantilla y las blondas de las mangas del vestido» (2013: 409). Además, la moda del majismo le ofrecía a la mujer petimetra de clase alta otro atractivo, que era aprovecharse de "las novedades que se introdujeron en la vida cortesana, pues además suponía una proyección pública y el disfrute de cierta liberalidad impensable unas décadas atrás» (Molina 2013: 381). La introducción de la costumbre italiana del cicisbeo (o en español chichisveo) en las primeras décadas del siglo XVIII, supuso aceptar en las casas nobles y de la alta burguesía a hombres para acompañar a las mujeres en la conversación. Su intención inicial era controlar el comportamiento sexual femenino, pero poco a poco llegó a "producir el efecto contrario, desautorizando de ese modo el control marital y otorgando a la mujer casada una libertad hasta entonces desconocida» (Molina 2013: 310). A mediados del siglo XVIII irrumpió la práctica del cortejo entre mujeres casadas y sus amantes, que, como demuestra el diario de Nicolás de Fernández de Moratín, pudo llegar incluso al acto sexual (Molina 2013: 325). En la literatura y pintura de la época se presentan mujeres que salían por las calles y parques públicos con sus cortejos, acompañadas de niños pequeños de la mano, que daban respetabilidad

14.- La palabra petimetra es la forma femenina de petimetre, procedente del francés, «petitmaître». 
a la escena. Las mujeres iban frecuentemente vestidas con ropa de maja, basquiña y mantilla, tal como se ve en las estampas anónimas La castañera madrileña y La petimetra en el Prado de Madrid (1795) (Molina 2013: 332-3). Goya retrataba a las mujeres de las clases más altas vestidas de majas, y hasta pintó con este atuendo a la reina María Luisa en el óleo María Luisa de Parma con mantilla (1799). Pero nota Molina que en los dibujos, siendo obras privadas, Goya tenía la libertad de reproducir a esas mujeres vestidas de majas con la misma visión acerba que tenía sobre las otras de clase más humilde. Por ello, en el dibujo Majas de paseo, que procede del Álbum A (1794-5), «el recato y buenas maneras de las señoras de distinción acompañadas de sus dueñas y cortejos se transforma en orgullo, altivez y descaro de mujeres sin ningún tipo de acompañante» (Molina 2013: 333). La distinción entre majas petimetras, que eran de clase alta, y prostitutas se borra en los dibujos de Goya, especialmente cuando dibuja la Maja y Celestina esperando debajo de un arco. En este cuadro se reproduce a Celestina con su rosario y cara típica ante la figura postrada de una maja, postura "provocativa» para Molina (2013: 335). Las majas de clase alta que Goya representa en sus dibujos y Caprichos son para Molina una crítica de la llamada «marcialidad» de la mujer española. Ramírez de Góngora en 1788 describía la «marcialidad» femenina como «el hablar con desenfado, tratar a todos con libertad y desechar los melindres de lo honesto", actitud que encontraba su homólogo en la supuesta feminización del hombre petimetre (Molina 2013: 401).

La moda ofrecía a cualquier pintor la oportunidad de demostrar su destreza con el pincel, ya que el brillo de las sedas y las líneas intricadas de los encajes ofrecían deleite visual y sensual tanto en la vida como en la pintura. Es en esta corriente donde hay que situar a Eugenio Lucas Velázquez, pues será ese interés por la suntuosidad visual de la moda del majismo y su subsiguiente adaptación por las clases altas, lo que le llevará a desanclar la temática celestinesca de la visión crítica de Goya. Es más, al ensalzar las superficies brillantes, lustrosas e intricadas de las sedas y los encajes, el artista devuelve la femineidad a esas majas masculinizadas por sus gestos y posturas marciales. No es que a Lucas Velázquez le faltara la visión crítica de la sociedad, pues pintó el cuadro alegórico La República guiando a España, al que Arnaiz considera «el primero pintado en España como exaltación del régimen republicano» (Reyero y Freixa 1999: 494). En su producción abundan cuadros que tratan de la Inquisición y son, según Reyero y Freixa, "donde late lo mejor del expresionismo goyesco, lejos, en este caso, de cualquier pintoresquismo trivial» (1999: 126). ${ }^{15}$ No

15.- Es posible que los cuadros de la Inquisición se refieran a la ejecución pública de un ex-monje que sufría de un trastorno mental, Martín Merino, quien atentó contra la vida de la Reina Isabel II. En 1852 fue ejecutado a garrote vil en un acto público que reprodujo algunos de los ritos del Santo Oficio, como fue el de hacerle pasear por la ciudad con una túnica amarilla con coroza, mientras iba en lomos de un burro (Arnaiz 1981: 17-19). 
obstante el hecho de que durante su vida fue tachado de ser hasta falsificador de Goya, el tratamiento que hace Lucas Velázquez de la temática celestinesca dista mucho de la visión goyesca, ya que el artista la asocia a un costumbrismo en el que se resaltan reuniones sociables de majos y majas vinculados al deleite sensual. ${ }^{16}$ Para Ginger, la «imitación» que hace Lucas Velázquez de Goya es un pastiche, estética poco común entre sus contemporáneos, pero que se puede asociar con la renovación de tradiciones españolas que surge en la pintura de su época (2007: 77-9). ${ }^{17}$

El acercamiento de Lucas Velázquez hacia las figuras de las majas no es una simple imitación de Goya, ya que Lucas las pinta de manera variada: solas, en compañía de otras majas y aun de hombres, o con celestinas en escenarios diferentes. El efecto de pastiche que caracteriza el arte de Lucas Velázquez se ve en dos cuadros de majas, ambos depositados en la actualidad en el Museo Carmen Thyssen de Málaga. En el cuadro al óleo de 1865, La maja del perrito, Lucas pinta a una mujer vestida a la moda de finales del siglo XviII, recostada en el campo con una posición que se asemeja a la de la famosa Maja vestida de Goya, y acompañada por un perrito faldero (Figura 14). La mirada franca y abierta que la mujer dirige al espectador así como la postura relajada y entreabierta de sus piernas sugiere una invitación sexual, al igual que el abanico cerrado que apunta hacia su regazo. La presencia del perro, a veces símbolo de la fidelidad conyugal, no descarta la posibilidad de un encuentro ilícito. Un perro aparece también en una ilustración del libro grabado por Enguídanos, en Poesías póstumas, de J. Iglesias (Salamanca, 1793), que satiriza la costumbre del cortejo, pues cuando la mujer casada lleva al galán a su cama, el perro empieza a ladrar, sonido que alerta al marido del peligro (Molina 2013: 322).

El paisaje que sirve de trasfondo para la maja vestida de Lucas Velázquez se parece al de los tapices de Goya; mediante un toque pastoril, dos campesinos guían su rebaño en tercer plano ante el cielo parcialmente nublado e iluminado mediante una luz crepuscular. La clara alusión visual, tanto a los cuadros de Goya como a las costumbres dieciochescas del cortejo, tiñen este cuadro de una nostalgia sentimental. Cuando Mesonero Romanos y Antonio Flores comentan la desaparición de las manolas tradicionales alrededor de 1850, Ginger argumenta que Lucas Velázquez

16.- Sobre las acusaciones que se lanzaban hacia Lucas Velázquez en su vida, véase Ginger $54-5$.

17.- El impulso liberal de crear un nacionalismo español de material vario y diverso con legados del pasado no fue, argumenta Ginger, una actividad que buscara una identidad esencialista sino una actividad de pastiche, pues incluso los legisladores de la Constitución de 1812 compilaron un corpus de las leyes que existieron entre los diferentes reinados españoles, creando, en palabras de Argüelles, un cuerpo legislativo «nuevo solamente en el orden y método de su disposición» (82). 
pinta a las majas como «visiones de un pasado nacional que, por bien o por mal, se reprimía» (2007: 262). ${ }^{18}$

El pastiche es más escurridizo en el caso del cuadro Pareja de majos (1842), ya que reproduce un escenario único en la iconografía celestinesca hasta ese momento. En este lienzo, una pareja de jóvenes de clase baja posa en un palco de una plaza de toros y una celestina, de aspecto no tan anciano, se apoya en un bastón a la derecha (Figura 15). Detrás de ellos, hacia la derecha, se perfila la corrida, sugerida mediante la figura borrosa del toro junto al matador y otro torero. El majo, caracterizado como gitano por el artista, lleva una capa roja similar a la del embozado que corteja a la maja, igualmente caracterizada como gitana en El paseo de Andalucía, o La maja $y$ los embozados (1777) de Goya, mientras su chambergo con cinta azul es reflejo del sombrero con cinta roja que lleva el majo sentado en el primer plano a la izquierda del mismo cuadro goyesco (Figura 16). Como nota Romero de Solís (2003: 206-8), la indumentaria del embozado sentado de Goya, que lo enmascara, estaba prohibida por el Real Decreto de 10 de marzo de 1766, que obligaba al recorte de las capas y las alas anchas de los sombreros, relegando simbólicamente a los toreros, entre otros, al «pueblo ínfimo». Este cuadro perteneció a la Real Fábrica de Tapices antes de ser transferido al Museo del Prado entre 1856 y 1857, lo que posibilitaría que Lucas Velázquez pudiera haberlo contemplado, configurando así el pastiche que Ginger ha descrito como constitutivo del estilo del artista. Reemplazar el balcón del burdel por el palco de la plaza de toros traslada la prostitución a un escenario insólito en la representación pictórica, aunque tal vez no discrepara tanto de la práctica. De hecho, Mariano José Larra y Mesonero Romanos asociaban a las majas con la delincuencia y asimismo veían en la tauromaquia una distracción para las clases bajas y al mismo tiempo una influencia malévola (Ginger 2007: 263). La maja participa plenamente del cortejo, dado que retira el abanico para mostrar la cara al galán a la vez que admite el roce entre sus cuerpos. La Celestina, pequeña y encorvada sobre su bastón, solo mira satisfecha a la pareja, pues no hace falta aquí que ella tenga que ingeniárselas para que los dos se conozcan ni que anime a la joven a entregarse. La corrida de toros ha servido de escenario y estimulante suficiente para que el encuentro tenga lugar.

Este afán por someter la temática celestinesca a intereses estéticos se nota en otros cuadros de Lucas Velázquez. Por ejemplo, en Las majas al balcón (1862, Museo del Prado) (Figura 17), la maja central, vestida suntuosamente de rojo y azul con toques dorados, está rodeada por dos muchachas que están de pie. Todas llevan flores abundantes en sus peinados y miran serenamente hacia el espacio exterior. El ambiente se presenta de

18.- Se lee en el inglés original: "In the light of such contemporary perceptions, Lucas's paintings of majas can be taken as visions of a distinct national past that, for better or for worse, was being repressed» (2007: 262). 
manera festiva a través de la guitarra, las guirnaldas de flores que adornan la barandilla, el pelo y la ropa de las majas. En las sombras de la derecha, donde en otros cuadros de la misma temática estaría Celestina, aparece una cara asombrada de mujer, tal vez la de una alcahueta. ${ }^{19}$ La misma pincelada así como el colorido añade un efecto ligero y brillante a la escena. Estudiante de Diego Velázquez, cuya obra copiaba en el Museo del Prado, así como de Goya, y amigo de Edouard Manet, Lucas Velázquez pintaba "con soltura y facilidad con gruesos de color sobrepuestos, que son los que dan a su pintura esos relieves brillantes, como esmaltados, en que la sombra de la materia propiamente dicha juega su propio papel» (Arnaiz 1981: 51). ${ }^{20}$ En este cuadro, así como en Pareja de majos, la relativa desaparición de Celestina está relacionada con la entrega plena de las majas a la seducción. En esta pintura, las tres chicas miran hacia el espectador, que ocuparía el espacio del cliente en dicho lugar, por lo que inclinan levemente la cara hacia la derecha de manera coqueta y le devuelven la mirada. Es la misma mirada que La maja del perrito dirige al espectador en un cuadro en el que tampoco aparece Celestina. En otras palabras, la Celestina se destaca cuando se potencia el control exterior sobre la maja por parte de la alcahueta. Puede que sea el mismo escenario el que ejerza influencia erótica sobre las mujeres en los cuadros que hemos analizado hasta el momento. La carga erótica, por decirlo así, del paisaje pastoril de La maja del perrito, de la corrida de toros de Majo y maja y del balcón adornado con flores y música, contribuye a crear lugares pictóricos ilusorios en los que un espectador podría convencerse de que la chica participa alegre y libremente de la transacción sexual.

De todos modos, en otras imágenes más sombrías de Lucas Velázquez se representa el control tradicional de Celestina. La Hispanic Society of America en Nueva York posee un gouache realizado por Lucas Velázquez, titulado Maja y celestina en el balcón, o anteriormente La hija de Ce-

19.- Pardo Canalis comenta haber visto una factura a nombre de Lucas «extendida por cierto comercio madrileño en 1861, referente a un suministro de material pictórico, en relación, sin duda, con los encargos del distinguido coleccionista gallego, Don Marcial de Torres Adadid, el que tenía en su posesión por lo menos veinticuatro obras del pintor, muchas de ellas «a la manera de Goya y otras a la de Teniers» (36). No hay que descartar, entonces, el interés que ciertos patrones parecen haber tenido en la temática celestinesca, sobre todo dada la venta en subasta de ciertos cuadros en años recientes.

20.- Sobre Lucas como proto-impresionista que proyecta su arte como un acercamiento temprano al impresionismo europeo, véase Gaya Nuño (1970: 80-81). Existe evidencia a través de la correspondencia entre Lucas Velázquez y Manet, pues los dos artistas trabajaron juntos (Lázaro 2012: 60). Camón Aznar precisa que el estilo de Lucas, al que el historiador de arte denomina «instantismo», se diferencia del impresionismo francés por su uso del negro, técnica aprendida de Goya, que ilumina «más las pasiones que las formas. La crispación de las actitudes, los claroscuros tan turbados, el garabato impregnado de angustia de tantas figuras de Lucas, han podido representarse en toda su tensión gracias a esa técnica fluida que no sujeta la imaginación y deja los rasgos apenas insinuados, pero en sus excrecencias definitivas» (59). 
lestina, fechado en 1847. En él se representa a la anciana y la maja en el típico escenario del balcón (Figura 18). Según Du Gué Trapier, Lucas realizó el dibujo como copia del cuadro de Goya, Celestina y maja al balcón, exhibido en una exposición de 1846 en El Liceo Artístico y Literario. En vez de ser copia fiel o pastiche del cuadro del maestro, es una interpretación sui generis de la escena ya típica, puesto que la pintura realizada por Lucas Velázquez se distingue no solo en la ejecución sino en la caracterización de las dos figuras femeninas. En el gouache, la joven está vestida de azul, con abanico blanco, mantilla oscura sobre los hombros y flores rojas en el peinado. Tiene un aspecto estatuario que el artista logra mediante su postura sólida, ya que se retira levemente de la barandilla y con una mano recoge la falda, así como por su expresión pasiva. Aunque la maja se exhibe plenamente, pues lleva el pecho descubierto y el abanico desplegado, que en la época significaba que el galán podía esperarla puesto que saldría inmediatamente, sin embargo el lenguaje corporal desmiente estas señales, descubriendo su indiferencia interior. ${ }^{21} \mathrm{Al}$ contrario, la maja de Goya se reclina sobre la barandilla, expone el pecho al espectador y sonríe abiertamente. La Celestina en la imagen de Lucas Velázquez está sentada a la izquierda, mirando hacia el suelo con aspecto melancólico a la vez que astuto. Aunque tiene facciones semejantes a la Celestina que aparece en el cuadro de Goya — nariz bulbosa así como frente prominente-, la pintada por Lucas no controla a la maja por estar detrás, ni interactúa con el espectador o cliente, sino que dirige la mirada hacia el suelo y en otra dirección. Al aislar a la alcahueta de la implícita transacción sexual, Lucas Velázquez pone en su rostro una vulnerabilidad que explica el por qué de su desagradable oficio, pues las dimensiones grotescas de sus facciones y de sus manos, que manipulan el rosario, denotan la soledad y pobreza de la vejez. Así pues, la escena ha perdido la tensión acerba que la marcaba en la visión goyesca a la vez que consigue retratar en la figura de la Celestina una personalidad más matizada, enajenada socialmente, vulnerable por su vejez y calculadora por necesidad.

No obstante, Lucas Velázquez hizo un par de obras celestinescas que se acercan al tema desde una perspectiva más siniestra, centrándose más en la figura de la alcahueta. Para el óleo sobre lienzo La maja, que también se titulaba anteriormente La hija de Celestina (hacia 1867), el artista llevó a cabo dibujos inspirados en los álbumes de Goya que versaban sobre asuntos celestinescos, entre ellos los preparatorios para los Caprichos

21.- El escritor anónimo del folleto Los abanicos. Su lenguaje expresivo (1887) cita otros muchos mensajes mediante el abanico, como: "El apoyar los labios en los padrones significa: No me fio; quitarse con ellos el cabello de la frente: No me olvides; abanicarse muy despacio: Ya me eres indiferente; pasear el índice por la varillas: Tenemos que hablar; entrar en la sala o salir al balcón abanicándose: Luego salgo; entrar cerrándolo: No salgo hoy; abanicarse con la mano izquierda: No coquetees con esa...» (1992: 52). 
(Figura 19). ${ }^{22}$ Entre los dibujos de Lucas Velázquez que imitan a Goya y que incluyen figuras de mujeres ancianas celestinescas se encuentran copias del Capricho 5, Tal para cual (Figura 21) y Capricho 27, ¿Quién más rendido? (Ansón Navarro 2009: 58). Alcalá Flecha comenta que el Capricho 5, Tal para cual (igual que el 28, Chitón) presenta la costumbre que tenían las mujeres de clase alta de emplear los servicios de celestinas para arreglar aventuras sexuales (1984: 130-4). En el cuadro de Lucas Velázquez, la maja sentada dirige su mirada hacia el espectador, pero se inclina hacia la silueta de una Celestina que susurra al lado. La Celestina revela las mismas facciones de siempre: nariz grande, barbilla protuberante, cejas dominantes y una frente alta, esta vez debida a la caída de cabello. Un mechón de pelo blanco, con tonalidades en verde, delinea la cabeza de la mujer, enfatizando así la estructura craneal. Con la excepción de las manos, el cuerpo de la alcahueta desaparece en la negrura, efecto que se añade a su aspecto siniestro. En el fondo a la izquierda, se percibe la cara y el sombrero oscuro del majo que entra por una puerta entreabierta. Aun menos sustancial que la Celestina, apenas se le nota la nariz bulbosa, las cavidades del ojo y los labios gordos. Es la maja la que ilumina el cuadro, mirando abierta pero pasivamente hacia el espectador. En este óleo Lucas Velázquez despliega toda su destreza con los efectos de claroscuro y colorido. ${ }^{23} \mathrm{Su}$ atención a la tela del vestido de la maja es probable que debiera más a la técnica de Diego Velázquez que a la de Goya. El encaje blanco que lustra con toques de oro y amarillo, contrasta con el rojo del cinturón, las flores en el cabello y el revestimiento de la mantilla de la maja. El perrito faldero, los folletines a sus pies y la guitarra a la izquierda, accesorios todos ellos que muestran un elevado nivel económico. A ello se añade la suntuosidad de la vestimenta, junto con los objetos que indican una posición socioeconómica más adinerada. Sin embargo, la Celestina que se acerca a la maja tiene el mismo aspecto que el de una calavera, mientras susurra a la oreja de la joven bella sus consejos. Existen diferentes posibilidades interpretativas: o se trata de una prostituta que trabaja en un burdel acomodado, o de una querida de un hombre casado adinerada, o de una mujer casada a quien la Celestina sirve como tercera en amores. ${ }^{24}$

22.- Se supone que Lucas conocía los álbumes de dibujos de Goya, ya que era un familiar del hijo del maestro Javier Goya y de su nieto Mariano, en cuya posesión estaban todos los dibujos antes de ser vendidos entre los años 1856 y 1860 (Ansón Navarro 2009: 12-13). Arnaiz titula este cuadro La hija de la Celestina.

23.- Gaya Nuño da al cuadro el título Alegoría (1970: 84).

24.- Lucas mantuvo una relación con Francisca Villamil durante las últimas décadas de su vida, de la que nacieron varios hijos ilegítimos, entre ellos el pintor Eugenio Lucas Villamil. Pardo Canalis sugiere que «la irregularidad de la situación familiar de Lucas llegase a influir, de alguna manera, en el reiterado aislamiento en que transcurrieron sus quince años postreros» (39). 
Lucas Velázquez también pintó un óleo sobre cobre, Estudio de una cabeza (hacia 1850-70) (Figura 20), relacionado con Celestina. Presente asimismo en el Museo Lázaro Galdiano, esta pintura representa a una anciana que lleva una cuerda con cuentas que parece un rosario; además tiene la misma cara con nariz bulbosa, mejillas hundidas y ojos astutos, características que identifican a la alcahueta en la iconografía celestinesca que parte de Goya. Es en este cuadro donde la temática celestinesca se vincula más fielmente con la vertiente goyesca satírica. Parece acoplarse aquí la Celestina con la dueña de los burdeles modernos, la que detiene a las prostitutas en «esclavitud» en esta nueva industria del libertinaje. Al compararlo con el Estudio de una cabeza de Lucas y la cara de la anciana que está en el centro de Capricho 5 (Figura 21), se nota parecido entre ambas caras, ya que las dos tienen cejas dominantes, el ceño fruncido, pómulos altos, mejillas hundidas y barbilla prominente. Lo que distingue el cuadro de Lucas Velázquez es la mirada malevolente y calculadora de la anciana, que mira hacia la audiencia de reojo, mientras que la anciana de Goya mira directamente al espectador con una sonrisa tan abierta que la hace parecer atontada. No cabe duda que en el Capricho de Goya la mujer vestida de maja goza del cortejo del galán y lo invita con su abanico abierto, por lo que la Celestina detrás de la pareja es cómplice del encuentro. Aunque es arriesgado avanzar interpretaciones del Estudio de una cabeza dada la falta de escenario, la malicia que expresa la vieja aportaría otro tono a cualquier encuentro iniciado o ingeniado por ella, y conferiría a la maja cierto papel de víctima. De hecho, la cabeza pintada por Lucas Velázquez se le parece tanto en el aspecto maligno cuanto en la mirada de soslayo a la Celestina que aparece en el cuadro a óleo de Goya, $\mathrm{Ma}$ ja y celestina al balcón (Figura 11). La mirada sesgada se repite en La maja de Lucas Velázquez del museo Lázaro Galdiano y, a pesar de que no se puede distinguir la expresión facial a causa de la oscuridad, es de suponer que la de la Celestina sería igualmente malévola. De hecho, la maja que escucha los consejos de la vieja destaca en este cuadro en términos visuales por su pasividad y palidez, pues no es la maja la que coquetea con el hombre del Capricho 5 para por fin entregarse a él. En resumen, se nota en los cuadros de celestinas y majas de Lucas Velázquez un nuevo acercamiento: la maja aparece más pasiva, casi una víctima; la Celestina, como un ser monstruoso, y el escenario como un lugar cerrado y lujoso.

Esta nueva perspectiva corresponde a reformas legales que repercutieron en la práctica de la prostitución, junto con las nuevas actitudes sociales hacia las prostitutas y alcahuetas. A mediados de siglo se introdujo en España el prostíbulo «tolerado», donde los hombres podían alternar entre sí en una casa de aspecto burgués, además de pagar por encuentros sexuales con las prostitutas allí encerradas. Después de la Restauración, en la década de los 40, se promulgaron leyes reglamentando las actividades de las «prostitutas y encubridoras» en Zaragoza, Jaén, Cádiz y Barcelona, 
como respuesta a la percepción de la población en las grandes ciudades de que las mujeres "públicas» controlaban cada vez más los cascos urbanos, sin olvidar el de ser portadoras de enfermedades venéreas, sobre todo la sífilis (Guereña 1997: 104-5). ${ }^{25}$ En 1850 salió clandestinamente una comedia anónima, La Tripona o la Casa del Trato, que dramatizaba este modelo de burdel, y se describe el escenario como "un salón decentemente amueblado» del barrio de Tripón en Cádiz (Guereña 2003: 563). La guitarra presente en La maja de Lucas Velázquez del Museo Lázaro Galdiano puede que sea representativa de la prostitución, ya que era común que los hombres pasasen por los burdeles después de ir de fiesta, o que las prostitutas buscasen clientes en espectáculos o cafés cantantes (Guereña 2003: 555; Díaz Olaya 235-40). Las disposiciones de algunos artículos sobre la prostitución en Jaén dictados en 1855 revelan la tendencia moralmente conservadora que tuvo este movimiento cultural que buscó con afán controlar la prostitución. Uno de sus mayores objetivos fue el de contener su práctica de "un modo escandaloso afectando a la moral pública» (Caro Cancela 178). Fue así por lo que los burdeles se retiraron de las calles principales y se hicieron a las propietarias de las casas de prostitución responsables "de los escándalos que en ellas ocurran, de cualquier deshonestidad que sus pupilas cometan en las puertas, ventanas o balcones, y de las conversaciones obscenas o groseras que puedan ser oídas por la vecindad». Fue en estos momentos cuando Lucas Velázquez optó por situar los espacios en los que se desenvuelven la Celestina y la maja en escenarios diferentes del balcón, justamente cuando las leyes empiezan a ilegalizar el ejercicio comercial de la prostitución desde portales abiertos a la calle. A la vez se reglamentaba la supervisión médica de la salud de las prostitutas a través de inspecciones hechas por médicos que trabajaban al servicio del Gobierno, en oficinas especializadas cuyos nombres denotan su función: "Comisión de Médicos-Higienistas», que actuaban para «la vigilancia sanitaria» (Guereña 1997: 127-8). ${ }^{26}$

25.- Fue en estos momentos cuando se publicaron las primeras leyes sobre el control de la prostitución en el siglo XVII, legislación que llegó a una primera reglamentación en Madrid en 1847, y posteriormente con las leyes de 1854-65. La reglamentación madrileña servió de modelo para otras ciudades españolas, al menos en 14 localidades. Sus leyes impulsaron la creación de burdeles, constituyendo "una real operación de limpieza urbana paralela a la que también se realizaba entonces con los pobres y los 'vagos' para construir nuevos espacios de sociabilidad urbana» (Guereña 1997: 132).

26.- No obstante, la eficacia higiénica del control médico de las prostitutas en una época anterior al descubrimiento de los antibióticos fue nula, por lo que la sífilis llegó a alcanzar entre la población madrileña tasas preocupantes. En La prostitución en la villa de Madrid (1909), Antonio Fernández Navarro, médico forense de la Audiencia de Madrid, argumenta contra la legalización de la prostitución e incluye una tabla con las causas de mortalidad infantil madrileña en el quinquenio 1900-1905, época en que la tasa estaba entre el 42\% y 59\%. Según él, casi un 20\% de estas muertes era debidas a la sífilis (Fernández Navarro 1909: 226). 
El oficio de alcahueta, que manejaba las transacciones callejeras, se transformó en el de la madama, que cuidaba de un espacio doméstico con apariencia burguesa; mientras que su función anterior de manejar la salud física de las prostitutas bajo su poder se cedía a los médicos y a la policía, que era enemiga de las prostitutas tal como se ve en los dibujos de Goya. Los efectos de dicha legalización y reglamentación de la prostitución fueron múltiples y contradictorios para las mujeres que la practicaban. Al encerrarlas en un burdel, se les limitaba su movimiento, aunque no las expulsaron ni las encarcelaron, como fue la práctica anterior. Al controlarlas médicamente, se aseguró un cierto nivel de salud física, aunque este proceso higiénico se convirtió en un control burocrático de la prostitución y de las mujeres que la ejercían. El comercio sexual pasó al control del estado, pues como nota Guereña, "iPor qué privarse en efecto de los dividendos generados por la legalización de la prostitución?» (1997: 132). Uno de los efectos de esta tolerancia fue la de crear para las prostitutas y madamas un espacio que estaba a la vez marginado e integrado en la sociedad española del XIX (Guereña 1997: 131). El reformista Enrique Solís Rodríguez describía este nuevo modelo como «establecimientos que a ciencia y paciencia de todo el mundo, y con autorización del gobierno, explotan la prostitución como cualquiera otra industria» (1877: 94). La "dueña» se queda con todo el dinero que llega a la mano de las "pensionistas», las cuales están sujetas a "la cadena de la esclavitud». Se llegó a ver a las prostitutas como víctimas de madamas malévolas y hasta demoníacas: "En este círculo diabólico ejerce la policía su vigilancia, cerciorándose del estado sanitario de las mujeres de la casa, por medio de una inspección médica periódica e ignominiosa. A las enfermas se les secuestra en el acto, y no pueden volver a ejercer su ejercicio sin un certificado en que conste oficialmente su curación" (Solís Rodríguez 1877: 94-5). Las que no se sometían a esa supervisión «diabólica» actuaban de manera ilegal, circulaban por las calles y se las tachaba, significativamente, de «insumisas» (Labanyi 2000: 116).

La representación de majas bellas e inocentes en todos los cuadros de Lucas Velázquez, y celestinas deshumanizadas y malévolas en otros muchos, concuerda con las nuevas perspectivas sociales y legales de las prostitutas y alcahuetas. Dos viajeros franceses, el novelista y literato Charles Nodier y el Conde Alphonse de Cailleux, notaron con disgusto durante su estancia en España en 1823 la necesidad de acudir a los favores viles de una tercera bien enterada para encontrar un burdel (Guereña 2008: 233). No hay que descartar que el deseo de cuidar la higiene de los servicios de las prostitutas se extendiera hasta supimir a las alcahuetas, por ser viejas prostitutas, y porque era desagradable para un hombre que se consideraba de clase superior tratar con ellas. En la Celestina de Rojas, la protagonista se imagina las reacciones del hidalgo Calisto frente a sus intervenciones, insultándola como "puta vieja», "alcahueta falsa» y pro- 
yectando sobre ella el origen de sus propios deseos sexuales: "ipor qué acrecentaste mis pasiones con tus promesas?» (Rojas 2000: 112). En el siglo XIX esta deshumanización de la alcahueta alcanza nuevos niveles que muestran una indignación pervertida, ya que mientras ella va perdiendo poder social y económico sobre las prostitutas, la ira hacia su persona va subiendo. Fernández Navarro describe a la Celestina como comerciante de «bestias de placer» que "seduce» a su buena «adquisición» con «la suntuosidad de sus trajes, para que sea admiración de sus clientes cuando se presenta en el salón» (1909: 148). Sin embargo, el reformista no deja lugar a dudas acerca de la naturaleza de dicho trato, ya que la Celestina venderá una prostituta si no produce lo suficiente, le privará de zapatos, medias y camisa, y le hará servir a cualquier cliente y trabajar a cualquier hora y día, aun cuando esté embarazada o menstruando (Fernández Navarro 1909: 149-50). Pero la mayor queja de Fernández Navarro es que, ya hacia 1909, el estado se ha convertido "en Celestina o meretriz que cobre, cual cobra el alma de la prostituta pobre o reglamentada» (1909: 248).

El mismo tono reformista había se escuchado hacía 73 años. En el ensayo breve escrito por Ramón Mesonero Romanos el 17 de abril de 1836, Número 3 del Semanario Pintoresco Español, se incluye un juicio más ajustado sobre la novela de Rojas. La obra es «joya preciosa de nuestra antigua literatura", que levanta en el lector del siglo anterior la misma reacción hipócrita que en el lector de "estos siglos de luces»: «Juzgaban en los demás como un crimen contra el honor, lo que respecto a sí propios calificaban de simple travesura, y esta baja moralidad se conformaba perfectamente con su instrucción y costumbres» (Semanario Pintoresco Español 1836: 32). El ensayo se imprime encabezado por una imagen diseñada por un tal Madrid y grabada en madera por Marquelain, que representa a Celestina. Al contrario de la visión oblicua que es la estereotípica, aquí se le ve directamente, quitándoles a la nariz y la barbilla las dimensiones grotescas que había adquirido a lo largo del siglo xIX (Figura 22). Estamos ante una Celestina humanizada que nos devuelve la mirada, no con el fin de engañar, sino que mira hacia el espectador para establecer una relación humana. No obstante su aprecio de la Celestina de Rojas, en otro ensayo escrito por Estébañez Calderón y publicado en Los españoles pintados por sí mismos en 1843-44, Mesoneros describe a las celestinas como figuras grotescas que sirven como conductos de contagio y que no tienen equivalente en las especies animales:

Y de tan feas cataduras como llevan y parecen estos instrumentos de la liviandad y del desordenado amor, ninguna presenta bulto más siniestro ni rasgos más elocuentemente malvados como la vejez femenil, que apoyando su máquina cascada y su magra y repugnante persona en un bordón encorvado, para no caer en la fosa de la sepul- 
tura a cada paso, toma placer incalificable y recóndita y maldita voluptuosidad en dar al traste con la entereza de las vírgenes, y en descalabrar las honras y la fama de las doncellas $(1844,2: 3)$.

El joven que busca un encuentro sexual con la novia del otro, pide ayuda a Celestina en su hogar ínfimo, el que el ensayista describe con metáforas infernales para rematar el aspecto diabólico de la alcahueta; luego pasa a describir la persuasión retórica con la que la vieja seduce a la inocente. El ensayo termina con una apelación a la modernidad, época en la que el número de celestinas se va reduciendo, ya que "la Celestina se considere como un peón que sobra", puesto que las "negociaciones del amor suelen hacerse directamente» (Los españoles pintados por si mismos 1844, 2:11). La respuesta "moderna» ante la intervención tradicional de la alcahueta, la que habitaba en su residencia mísera y susurraba a la oreja de la doncella, es la del prostíbulo moderno, que se decoraba como salón burgués y que servía como espacio de sociabilidad masculina. No hacía falta avergonzarse por acudir y llamar a la puerta del prostíbulo en una calle de mal nombre, pues en los nuevos salones todos los hombres de buena clase se reunen para charlar, jugar a naipes y fumar antes de pasar a las habitaciones de las muchachas (Guereña 2003: 560-4). Sin embargo, el que hizo el dibujo para el grabado en este caso es Leonardo Alenza y Nieto, quien nos presenta una visión menos grotesca de Celestina, pues es de mediana edad y está vestida de negro (Figura 23). Lleva rosario, pero la única señal que identifica su oficio y que la distingue de las otras mujeres es el recado que trae en la mano. Alza la mirada y anda con dignidad por la calle, ya que ésta no es la figura de una vieja diminuta, corcovada ni siniestra que habita en las sombras. Las facciones de su cara son fuertes pero no grotescas. En estas dos ilustraciones provenientes de publicaciones de gran circulación, las celestinas no se someten a una visión satírica, grotesca o caricatural. Esta ecuanimidad de perspectiva ante la alcahueta introduce en la iconografía celestinesca otra vertiente, la de Picasso, que la retrató en su famoso cuadro del periodo azul, la Celestina de 1904. 


\section{Bibliografía}

Alcalá Flecha, Roberto. Matrimonio y prostitución en el arte de Goya. Cáceres: Universidad de Extremadura, 1984.

Angulo Íñıguez, Diego. "Murillo y Goya». Goya. Revista de Arte. Número extraordinario 148-50 (1979): 210-13.

Anónimo. Los abanicos. Su lenguaje expresivo. Con detalles de los alfabetos Dactilológico y campilológico. Barcelona: Montaner y Simon, 1887. Reimpresión Valencia: Librerías París-Valencia, 1992.

Ansón Navarro, Arturo y Ricardo Centellas Salamero. La estela de Goya. Discípulos y seguidores interpretan la obra del maestro. Zaragoza: Diputación Provincial de Zaragoza, 2009.

Arnárz, José Manuel. Eugenio Lucas. Su vida y su obra. Madrid: M. Montal, 1981.

Bozal, Valeriano. "Dibujos grotescos de Goya». Anales de Historia del Arte. Volumen Extraordinario (2008): 407-26.

CAmón Aznar, José. "Discurso de contestación». Eugenio Lucas y su mundo. Discurso leido por el Excmo. Sr. Don Enrique Pardo Canalis con motivo de su recepción pública el día 13 de junio de 1976. Madrid: Real Academia de Bellas Artes de San Fernando, 1976: 49-61.

Caro Cancela, Diego. "Una aproximación a la prostitución en el Jerez del siglo XIX». "Mal Menor». Políticas y representaciones de la prostitución (Siglos XVI-XIX). Ed. Francisco J. Vázquez. Cádiz: Universidad de Cádiz, 1998: 169-81.

Díaz Olaya, Ana María. "Los cafés cantantes y su influencia en la actividad musical de la sociedad española de finales del siglo XIX y principios del siglo xx. El núcleo minero de Linares como ejemplo de avance cultural y artístico». Boletín. Instituto de Estudios Giennenses 205 (enerojunio 2012): 233-46.

Du Gué Trapier, Elizabeth. Eugenio Lucas y Padilla. New York: Hispanic Society of America, 1940.

EsDaile, Charles J. Women in the Peninsular War. Norman: U of Oklahoma P, 2014.

Férnandez Navarro, Antonio. La prostitución en la villa de Madrid. Madrid: R. Rojas, 1909.

Fernández Rivera, Enrique. "The Images of Celestina and its Visual Culture». En Companion to 'Celestina'. Ed. Enrique Fernández Rivera. Leiden: Renaissance Society of America y Brepols, en prensa.

Gaya Nuño, Juan Antonio. «El centenario de Eugenio Lucas. El glorioso olvido». Goya 98 (1970): 77-85.

Ginger, Andrew. Painting and the Turn to Cultural Modernity in Spain. The Time of Eugenio Lucas Velázquez (1850-1870). Selinsgrove: Susquehanna UP, 2007. 
Goffman, Erving. Behaviour in Public Places. Notes on the Social Organization of Gatherings. New York: Free P, 1963.

Goya and the Spirit of the Enlightenment. Eds. Alfonso E. Pérez Sánchez y Eleanor A. Sayre. Boston: Museum of Fine Arts, 1989.

Goya. Images of Women. Ed. Janis A. Tomlinson. New Haven: Yale UP, 2002.

Goya. Un regard libre. Lille. Palais des Beaux-arts. 12 décembre 1998-14 mars 1999. Paris: Éditions de la réunion des musées nationaux, 1998.

Gudiol, José. Goya 1746-1828. Biography, Analytical Study and Catalogue of His Paintings. Trad. Kenneth Lyons. Vol. 1. New York: Tudor, 1971.

GuereÑa, Jean-Louis. «El burdel como espacio de sociabilidad». Hispania 63:2 num. 214 (2003): 551-70.

-. "Prostitution and the Origins of the Government Regulatory System in Nineteenth-Century Spain: The Plans of the Trieno Liberal, 18201823». Journal of the History of Sexuality 17:2 (May 2008): 216-34.

- «Prostitución, estado y sociedad en España. La reglamentación de la prostitución bajo la monarquía de Isabel II (1854-1868)». Asclepio 49:2 (1997): 101-32.

HAIDT, Rebecca. Women, Work and Clothing in Eighteenth-Century Spain. Oxford: Voltaire Foundation, University of Oxford, 2011.

Harrison, Nikki. "Nuns and Prostitutes in Enlightenment Spain». Journal for Eighteenth-Century Studies 9:1 (March 1986): 53-60.

Helman, Edith F. «The Elder Moratín and Goya». Hispanic Review 23:3 (July 1955): 219-30.

LabAnyI, Jo. Gender and Modernization in the Spanish Realist Novel. Oxford: Oxford UP, 2000.

LÁzAro, José. «Lucas, padre e hijo». Eugenio Lucas Velázquez. Eugenio Lucas Villamil. Colección Lázaro. Torreón de Lozoya. Salas de Palacio. Del 27 de junio al 4 de noviembre de 2012. Segovia: Caja Segovia. Obra Social y Cultural/Fundación Lázaro Galdiano, 2012: 51-61.

López VÁzouez, José Manuel B. «Prostitución y celestinaje en tres Caprichos de Goya: el engaño y la mentira como las enfermedades más viejas del reino». Semata, Ciencias Sociales e Humanidades 21 (2009): 201-24.

Los españoles pintados por sí mismos. Madrid: I. Boix, 1844 y 1851.

MolinA, Álvaro. Mujeres y hombres en la España ilustrada. Identidad, género y visualidad. Madrid: Cátedra, 2013.

Museo del Romanticismo. La colección. The Collection. Madrid: Ministerio de Cultura, Subdirección de Publicaciones, Información y Documentación, D.L., 2011.

Palencia Tubau, Ceferino. Leonardo Alenza. Madrid: Saturnino Calleja, sf.

Palomo, María del Pilar. "La imagen de la mujer en el Semanario pintoresco españoly. Arbor. Ciencia, pensamiento y cultura 188:757 (septiembreoctubre 2012): 937-44.

Pardo Canalis, Enrique. Eugenio Lucas y su mundo. Discurso leído por el Excmo. Sr. Don Enrique Pardo Canalis con motivo de su recepción pública el día 
13 de junio de 1976. Madrid: Real Academia de Bellas Artes de San Fernando, 1976: 7-48.

Puelles Romero, Luis. «La representación de la 'mujer pública' en el arte moderno». "Mal Menor». Politicas y representaciones de la prostitución (Siglos XVI-XIX). Ed. Francisco J. Vázquez. Cádiz: Universidad de Cádiz, 1998: 101-36.

Ramos VÁzouez, Isabel. «Policía de vagos para las ciudades españolas del siglo XVIII». Revista de Estudios Histórico-Jurídicos 31 (2009): 217-58.

Ribeiro, Aileen. "Fashioning the Feminine: Dress in Goya's Portraits of Women». En Goya. Images of Women. Ed. Janis A. Tomlinson. New Haven: Yale UP, 2002: 71-87.

Rodríguez Simón, Luis Rodrigo. "Maja y celestina. Una nueva pintura sobre alabastro en el catálogo de Francisco Goya». Cuadernos de Arte de la Universidad de Granada 44 (2013): 145-70.

Rodríguez-Solís, Enrique. La mujer, defendida por la historia, la ciencia y la moral. Madrid: El Imparcial, 1877.

RojAs, Fernando de. La Celestina. Tragicomedia de Calisto y Melibea. Ed. Francisco Rico et al. Barcelona: Crítica, 2000.

Romero DE Solís, Pedro. «La montera. Un complemento indumentario entre la naturaleza y la cultura». Revista de Estudios Taurinos 16 (2003): 195-238.

Rubio Cremades, Enrique. "Los peligros de Madrid en El Semanario Pintoresco Españoly. Arbor. Pensamiento, Ciencia, Cultura 188:757 (septiembreoctubre 2012): 869-80.

Salas García, Bárbara y Beatriz Sánchez Hita. "La calle, la mancebía y la galera: Una aproximación a la prostitución a través de la literatura dieciochesca». Cuadernos de Ilustración y Romanticismo 8 (2000): 71-91.

Schiff, Gert. Picasso. The Last Years, 1963-1973. New York: The Grey Art Gallery and Study Center, 1983.

Semanario Pintoresco Español. Número 3. 17 abril 1836.

Snow, Joseph T. «Peripecias dieciochescas de Celestina». Actas de XIII Congreso de la Asociación Internacional de Hispanistas. Eds. Florencio Sevilla y Carlos Alvar. Madrid: Castalia, 2000: 2:39-46.

TomLinson, Janis A. Goya in the Twilight of Enlightenment. New Haven: Yale UP, 1992.

Torres González, Fernanda Begoña. Leonardo Alenza (1807-1845). Dibujos y estampas. Museo Romántico. Madrid: Ministerio de Educación y Cultura, 1997.

WATTS, Sarah. «Disparate matrimonial. A Bleak Future for an Enlightened Society». Romance Quarterly 54:1 (Winter 2007): 25-30.

Wilson-Bareau, Juliet. Goya. Drawings from His Private Albums. London: Hayward Gallery, 2001. 
vitien nada poedo negar. Solamente me falta sincerame con aquellos que de biena te creen que toilo lo que se cseribe es porqur si sabe prieticamente ó aconsejado par la experiencie. Este caso es una escepcion: si abora se Irvantara un nuevo Herókes, yo seria tal xex el primer inocente que secrificara. Cunntodejo dicho es liel traskarlo ile lo que un amizo me couto. amigo anciano ya ; pero

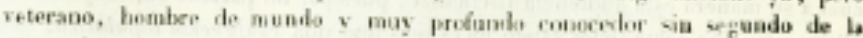
Moger del nwnilo.

TOMAS RODNGUEz RUBr.

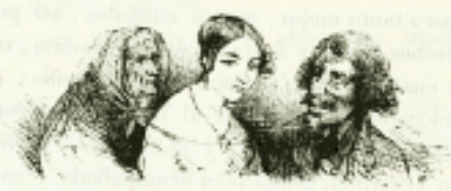

Figura 1

Anónimo. Los españoles pintados por sí mismos, 1851: 246. 


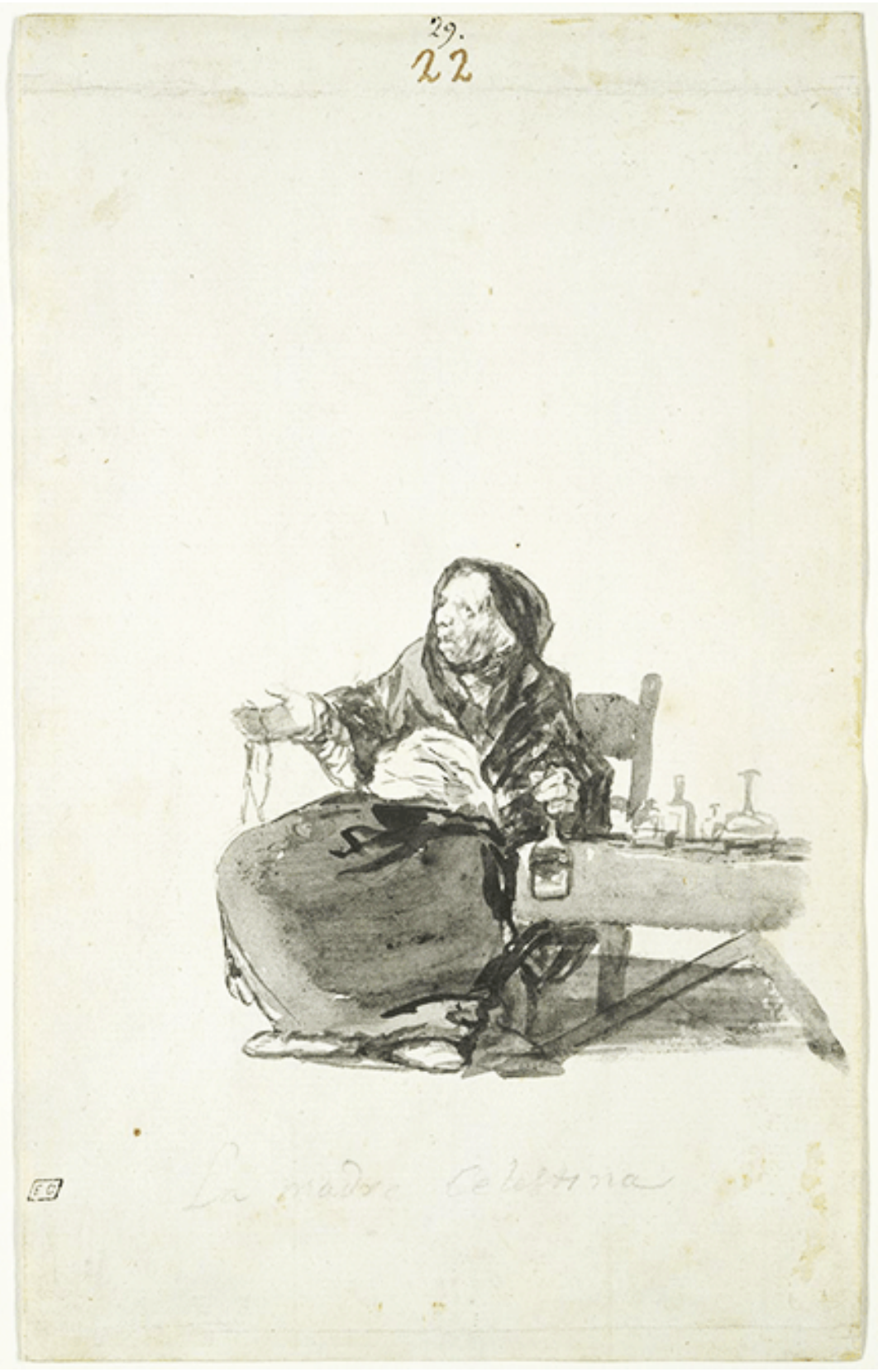

Figura 2

Francisco de Goya, Mother Celestina (La madre Celestina), 1819-1823. Museum of Fine Arts, Boston. 
vitien nada poedo negar. Solamente me falta sincerame ean aquellos que de boena te creen que toilo lo que se eseribe es porque se sabe prictiormente o aconsejado par la eqperiencie. Este cnso es una escepciom: si abora se levantara un nuevo Herókes, yo seria tal vex el primer inocente que sacrificira. Cuanto dejo dicho es liel traskato ile lo que un amizo one conts, amigo anciano ya ; pero

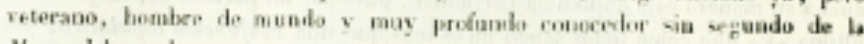
Moger del mwrilo.

TOMAS RODNTGUEz RUBr.

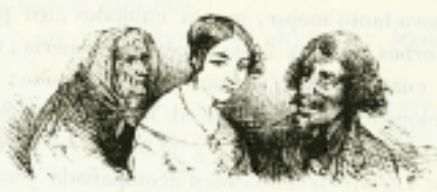

Figura 1

Anónimo. Los españoles pintados por sí mismos. 1851: 246. 


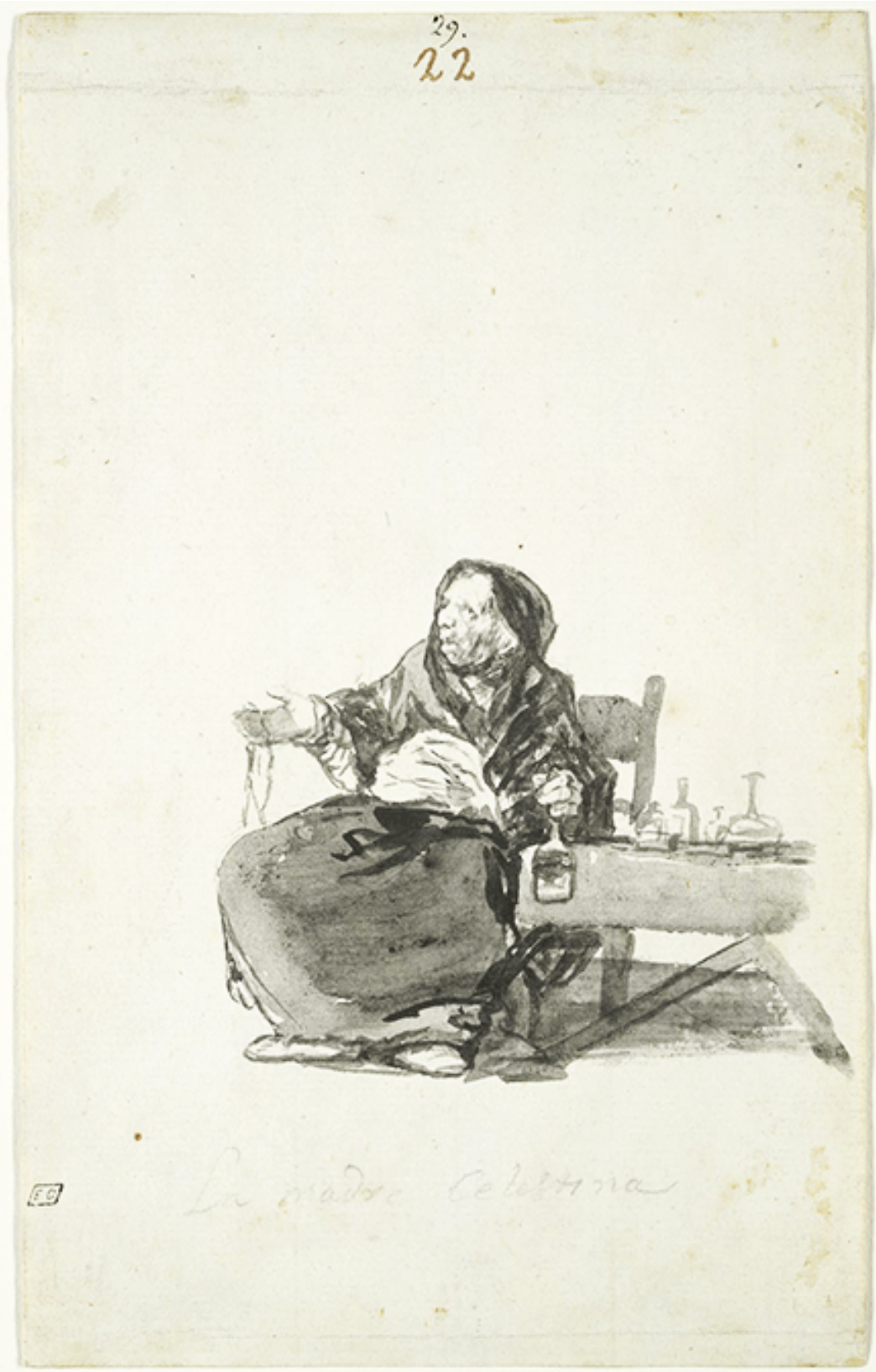

Figura 2

Francisco Goya, Mother Celestina (La madre Celestina), 1819-1823. Museum of Fine Arts, Boston. 


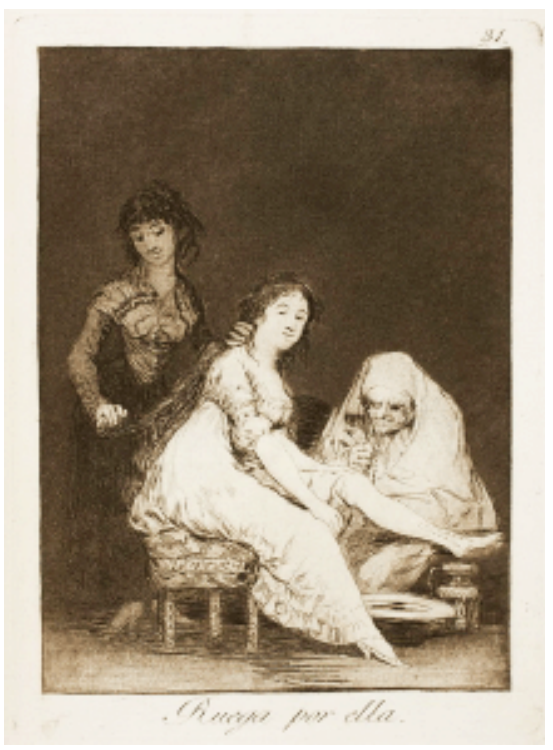

Figura 3

Francisco de Goya, Capricho 31, «Ruega por ella», 1797-1799. Museo del Prado.

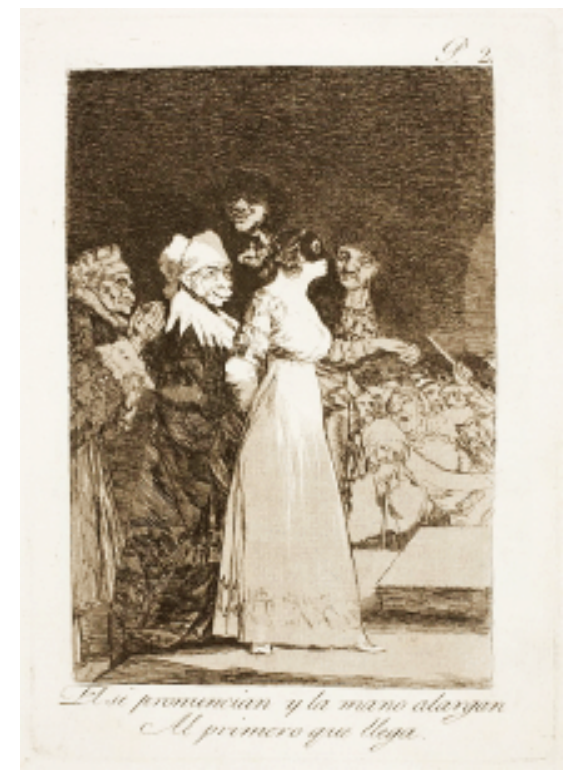

Figura 4

Francisco de Goya, Capricho 2, El si pronuncian y la mano alargan al primero que llega, 1797-1799. Museo del Prado. 


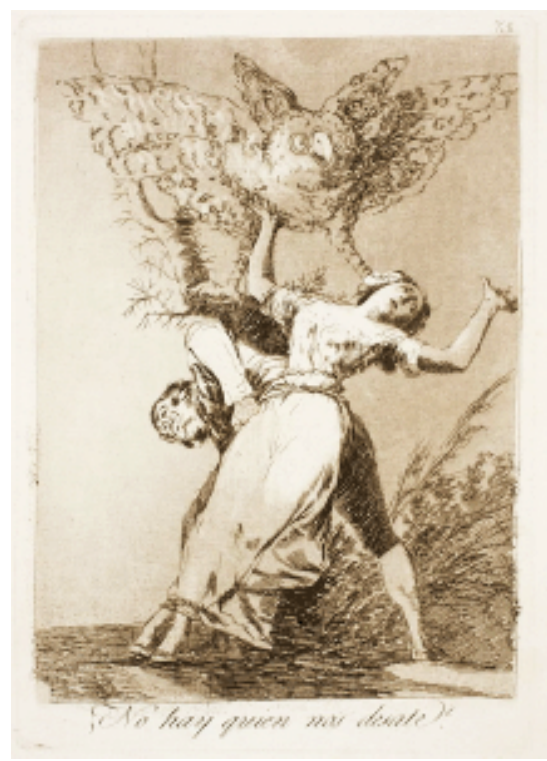

Figura 5

Francisco de Goya, Capricho 75, ¿No hay quien nos desate?, 1797-1799. Museo del Prado.

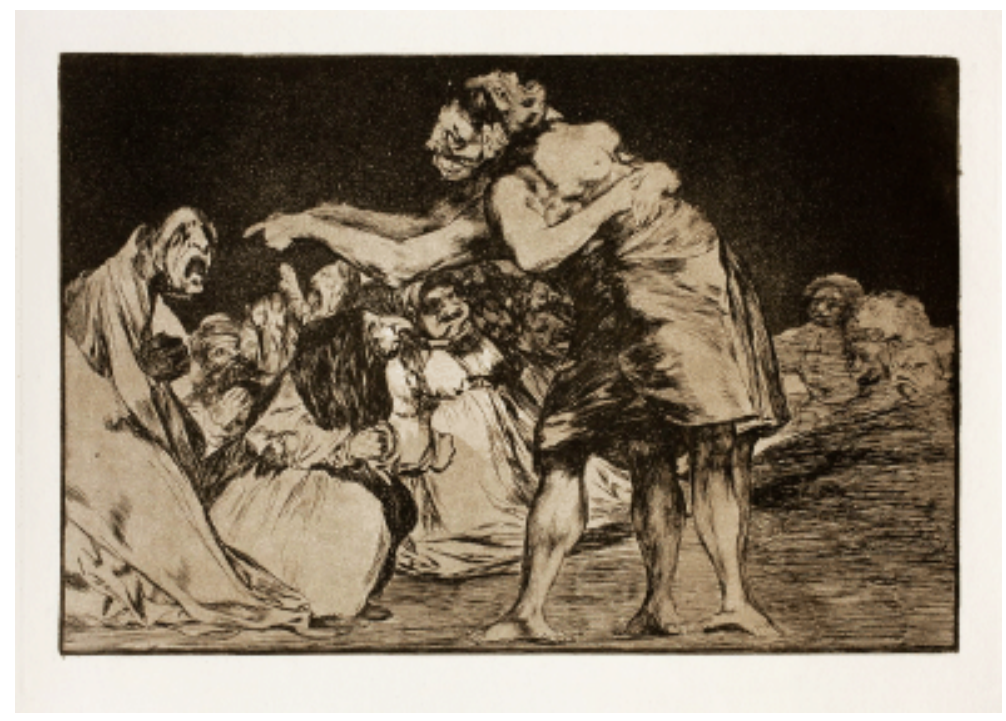

Figura 6

Francisco de Goya, Disparate matrimonial, 1815-1819. Museo del Prado. 


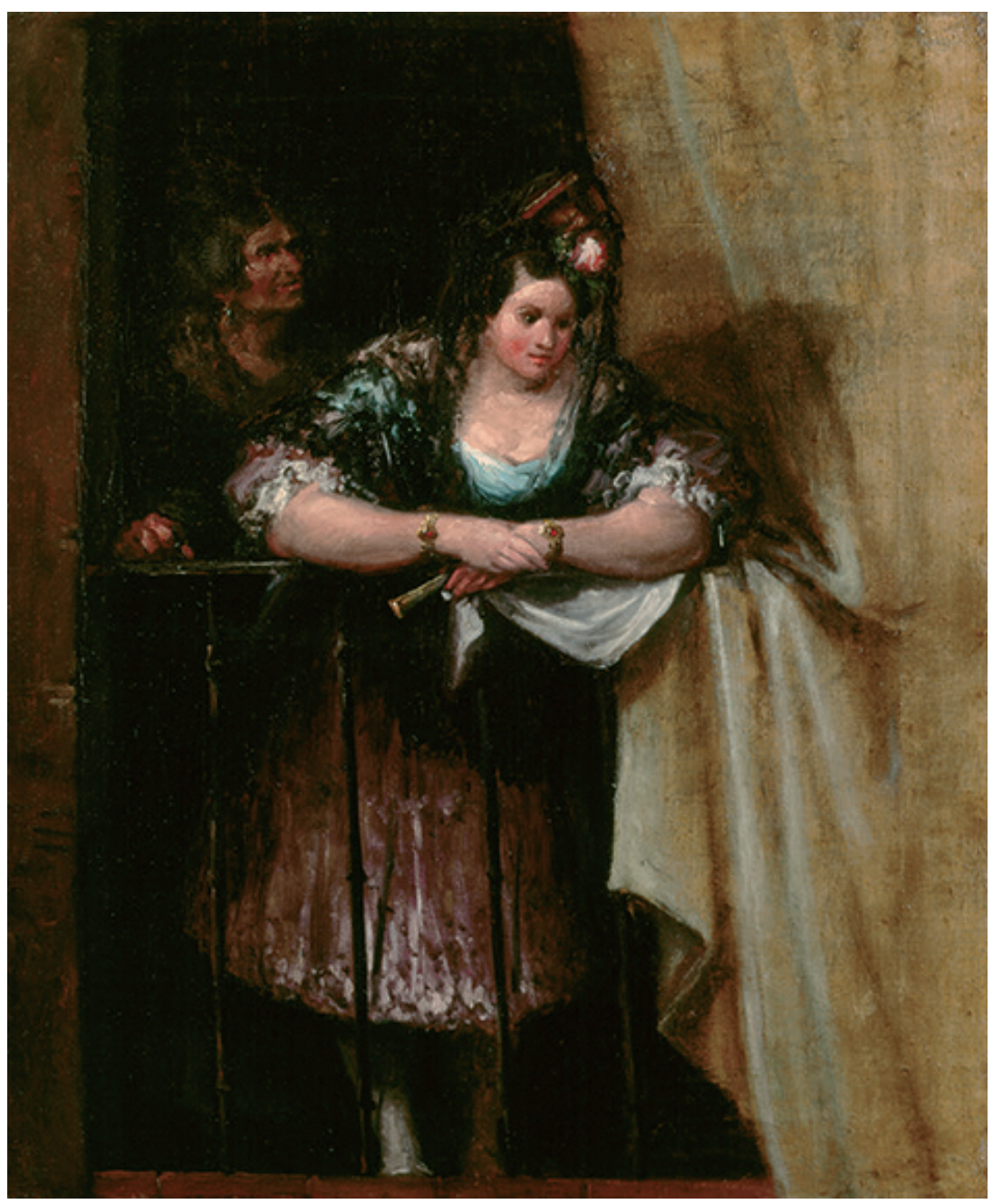

Figura 7

Leonardo Alenza y Nieto, La maja del balcón, c. 1840. Museo de Bellas Artes, Bilbao. 


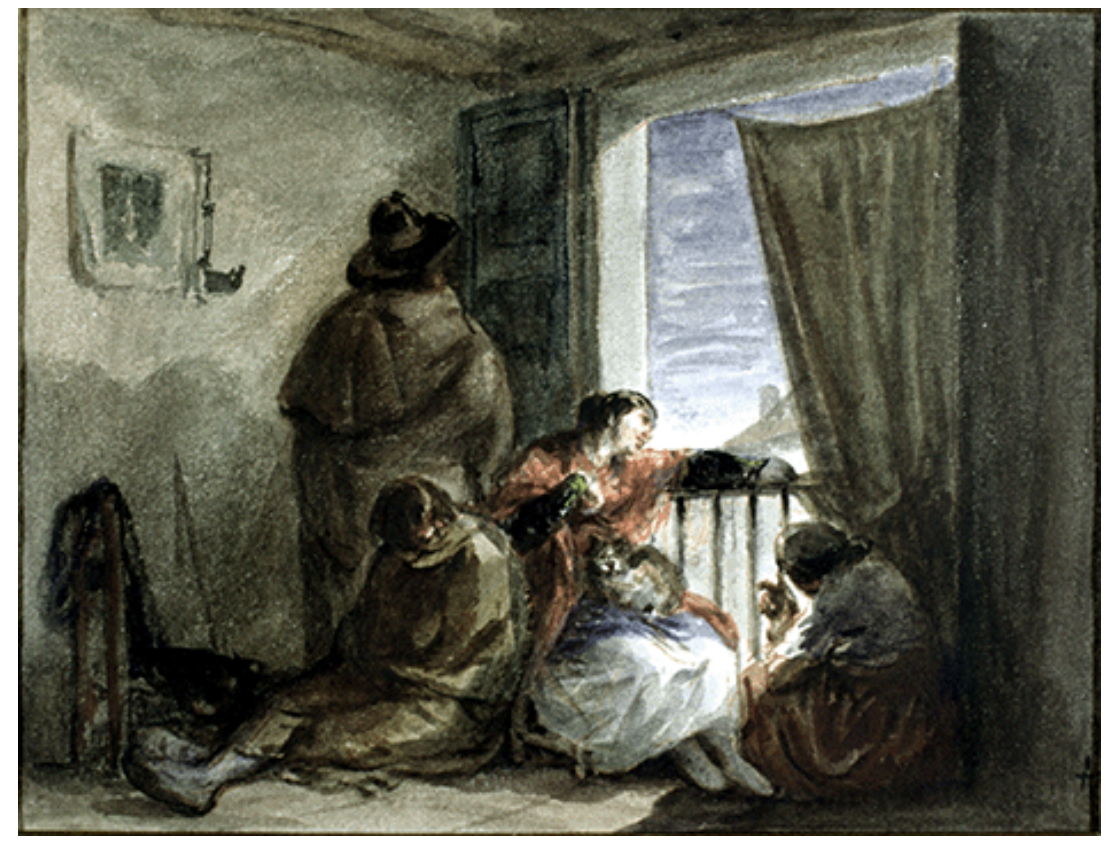

Figura 8

Esperando en el balcón de Leonardo Alenza y Nieto. № de inventario 10089. (c) Museo Lázaro Galdiano. Madrid. c. 1835. 


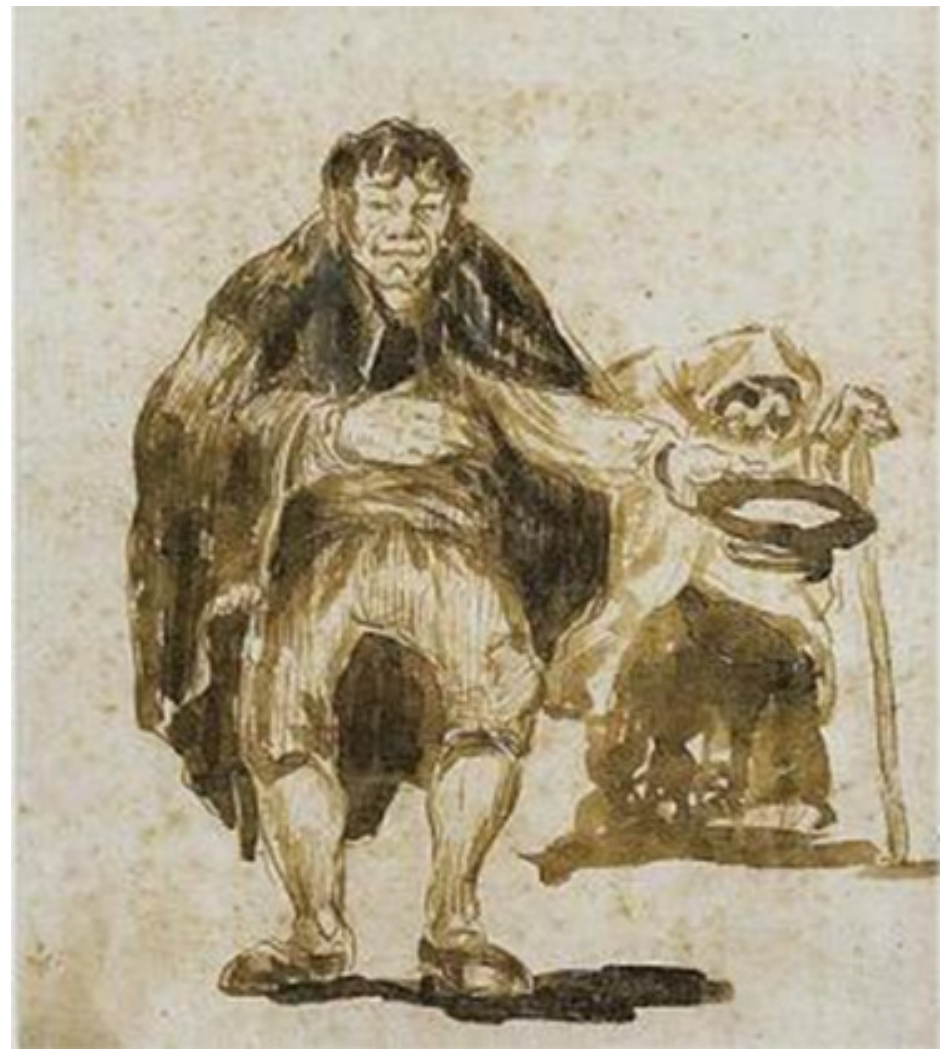

Figura 9

Leonardo Alenza y Nieto. Pobre y Celestina. sf. 


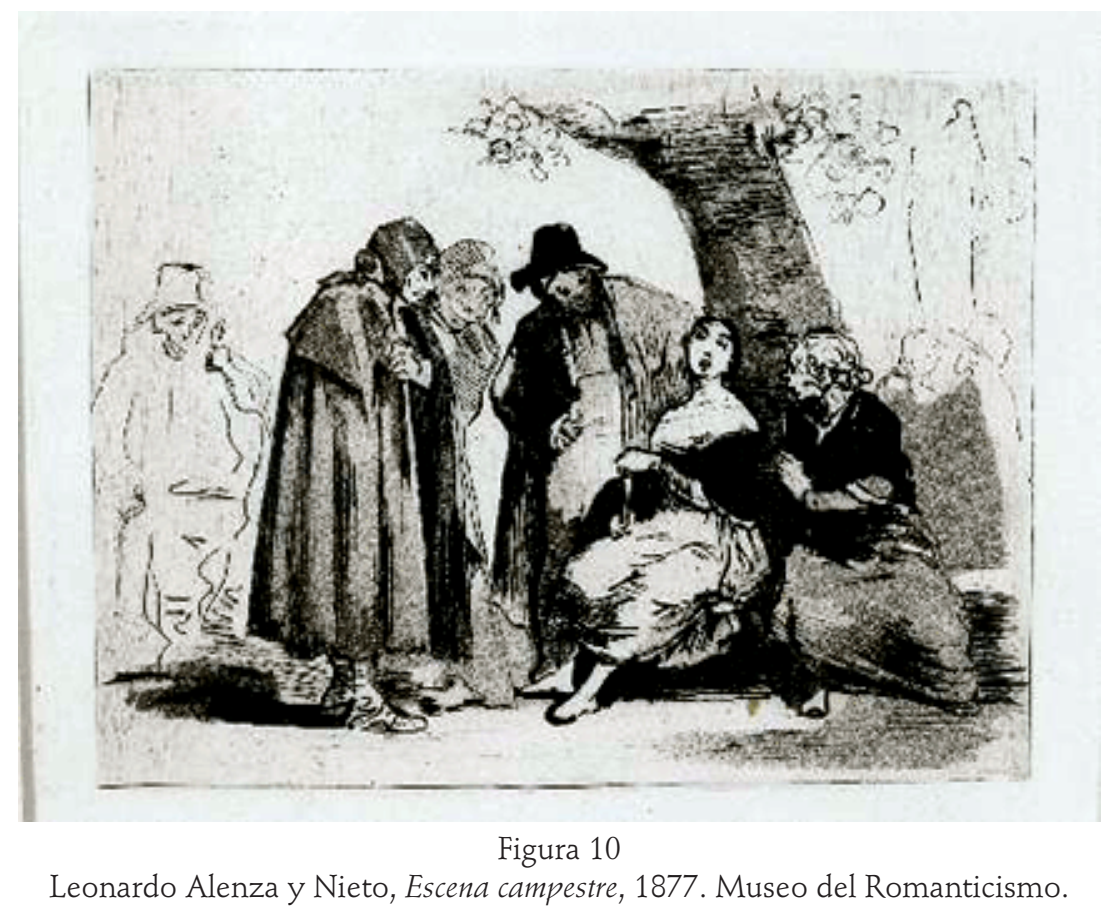




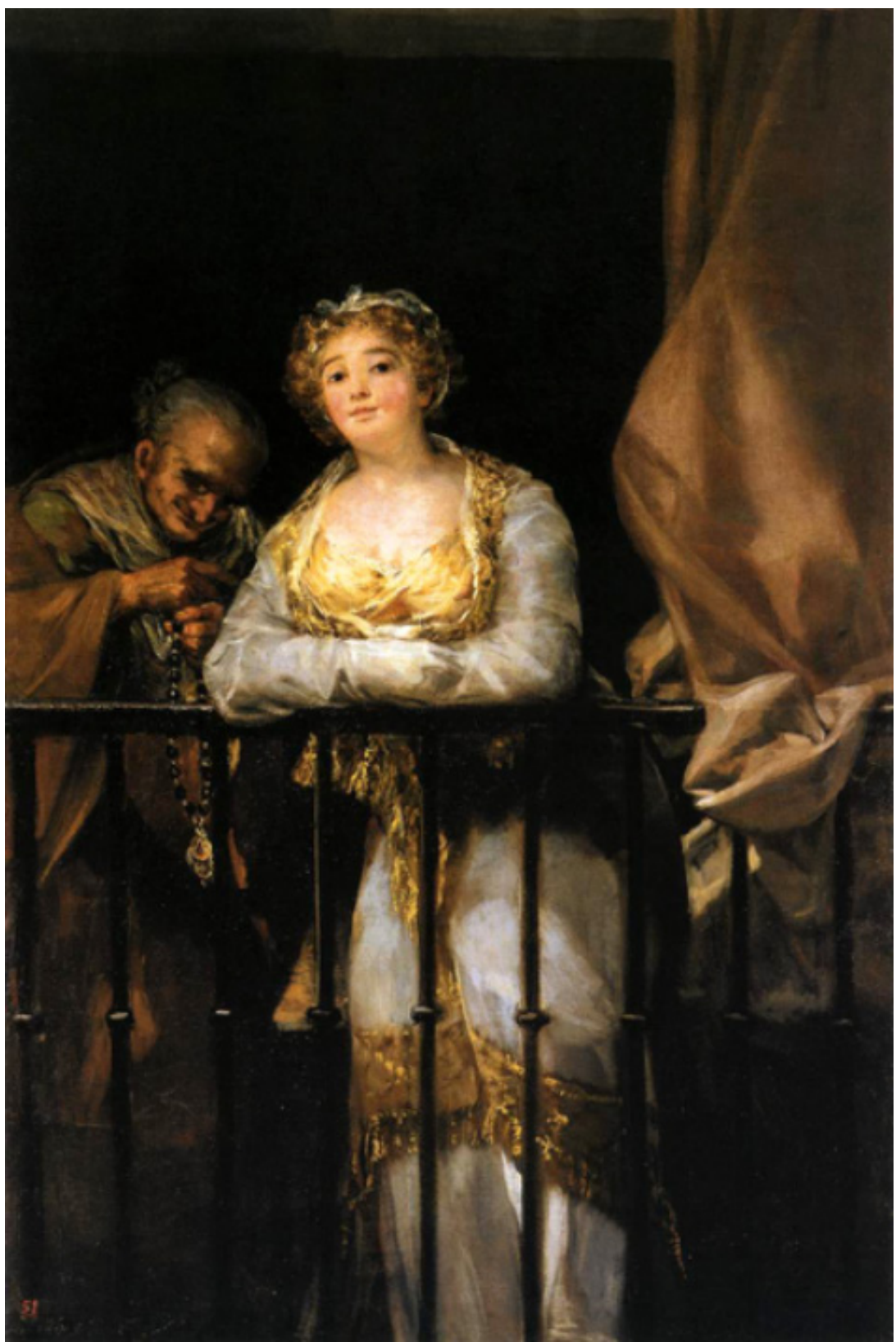

Figura 11

Francisco de Goya, Maja y celestina al balcón. 1808-1812. 


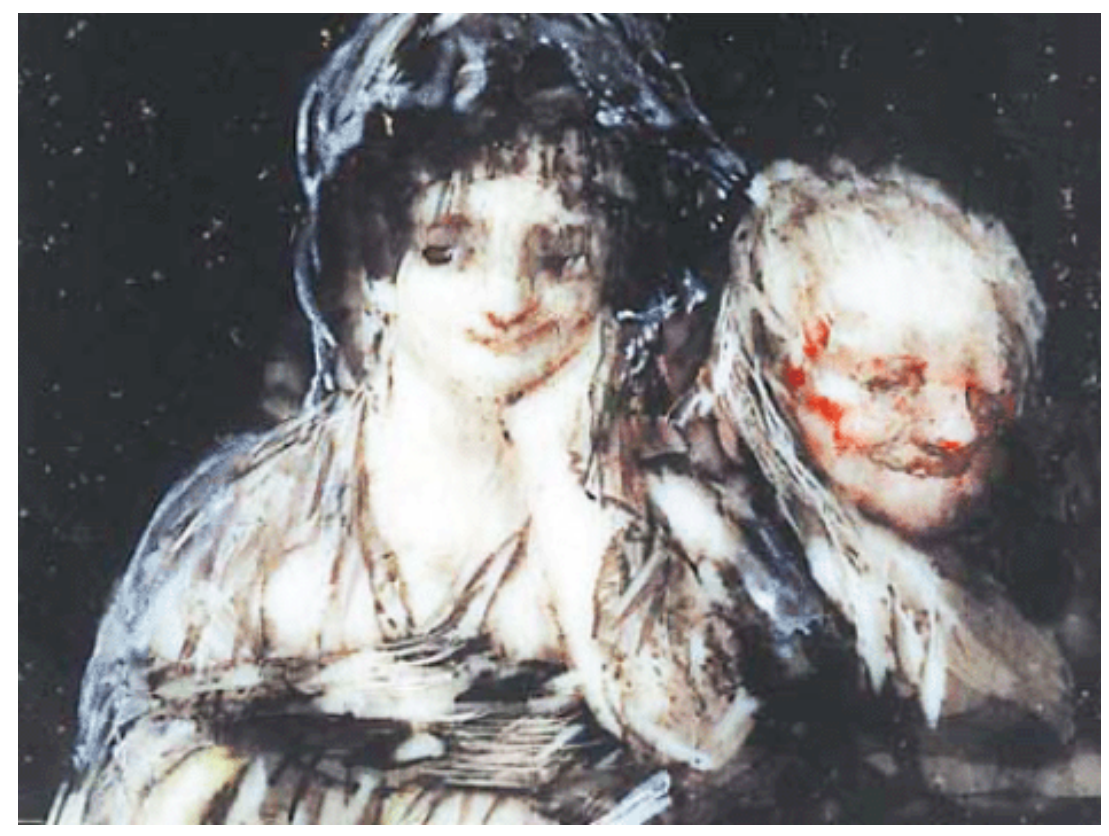

Figura 12

Francisco de Goya, Celestina y maja. 1824-25. 


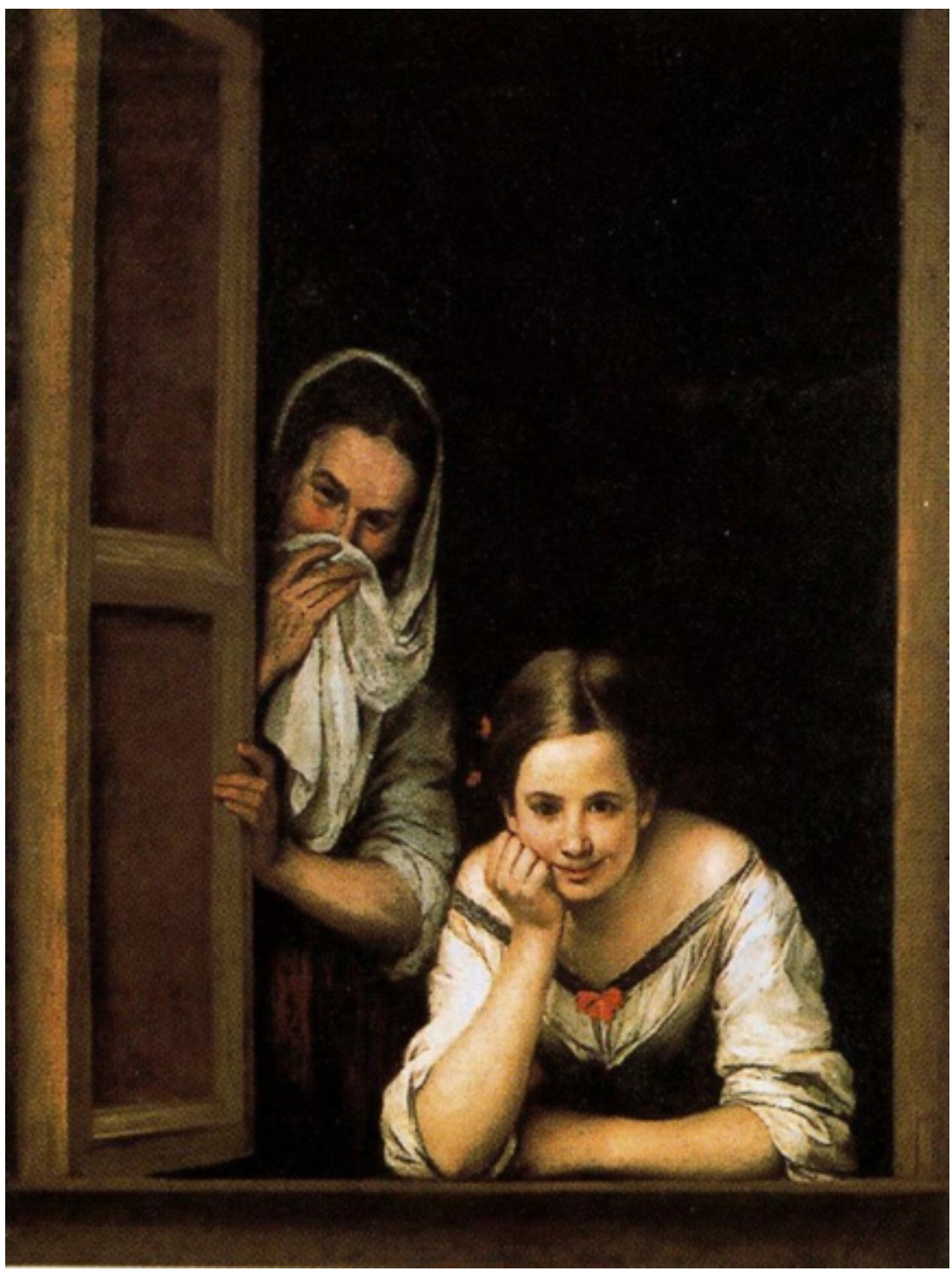

Figura 13

Bartolomé Esteban de Murillo, Mujeres en la ventana, c. 1655/1660. National Gallery of Art, Washington, D.C. 


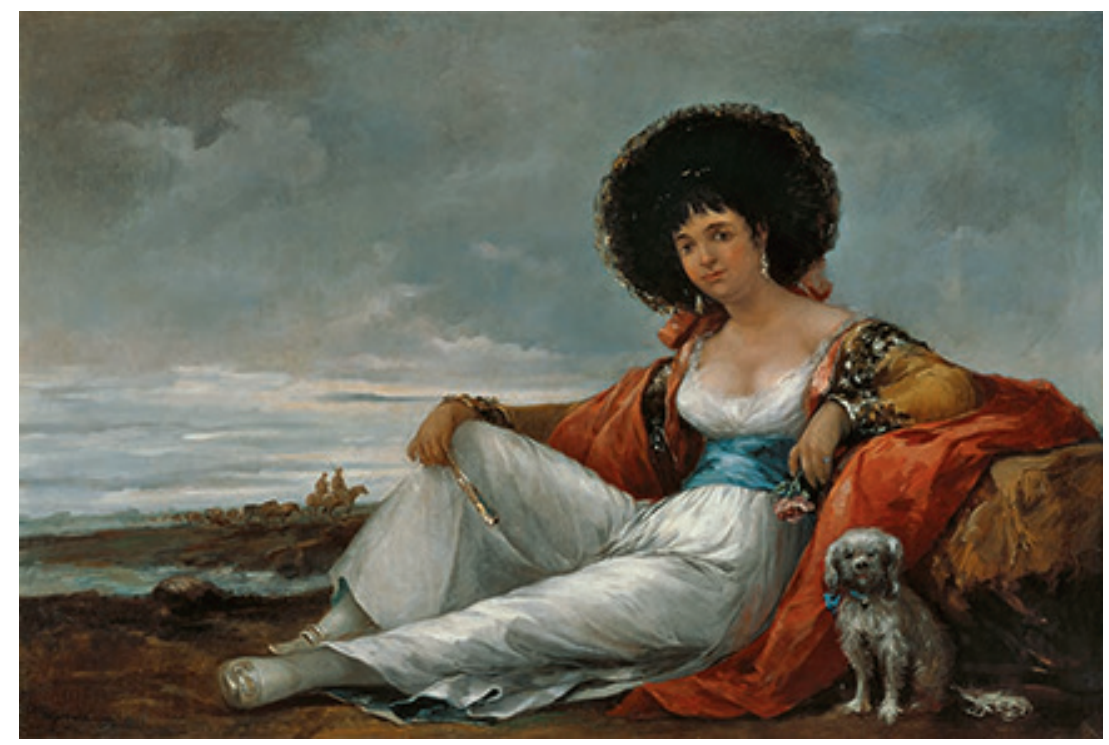

Figura 14

Eugenio Lucas Velázquez, La maja del perrito, 1865.

(C) Colección Carmen Thyssen-Bornemisza

en préstamo gratuito al Museo Carmen Thyssen Málaga 


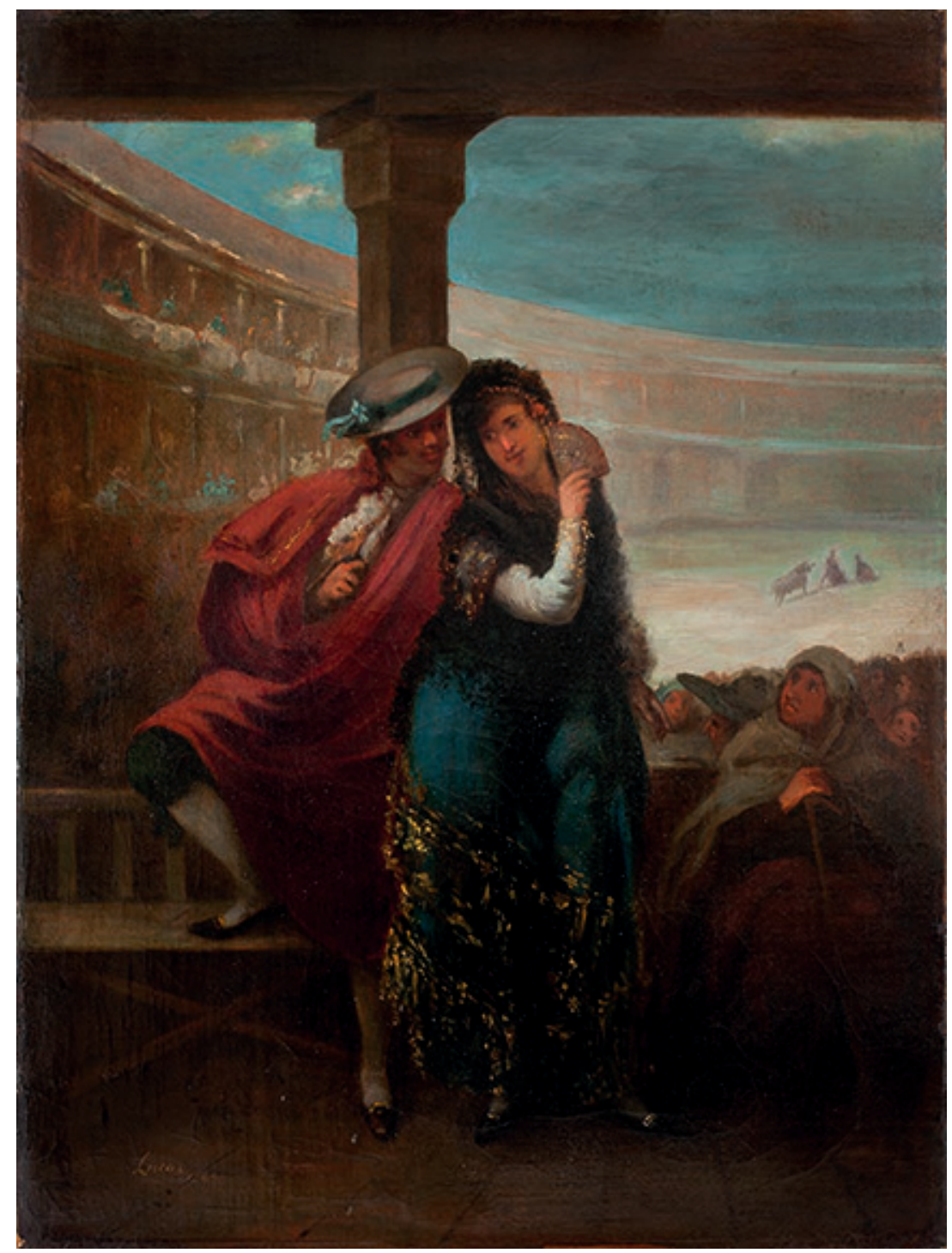

Figura 15

Eugenio Lucas Velázquez, Pareja de majos, 1842.

(C) Colección Carmen Thyssen-Bornemisza en préstamo gratuito al Museo Carmen Thyssen Málaga 


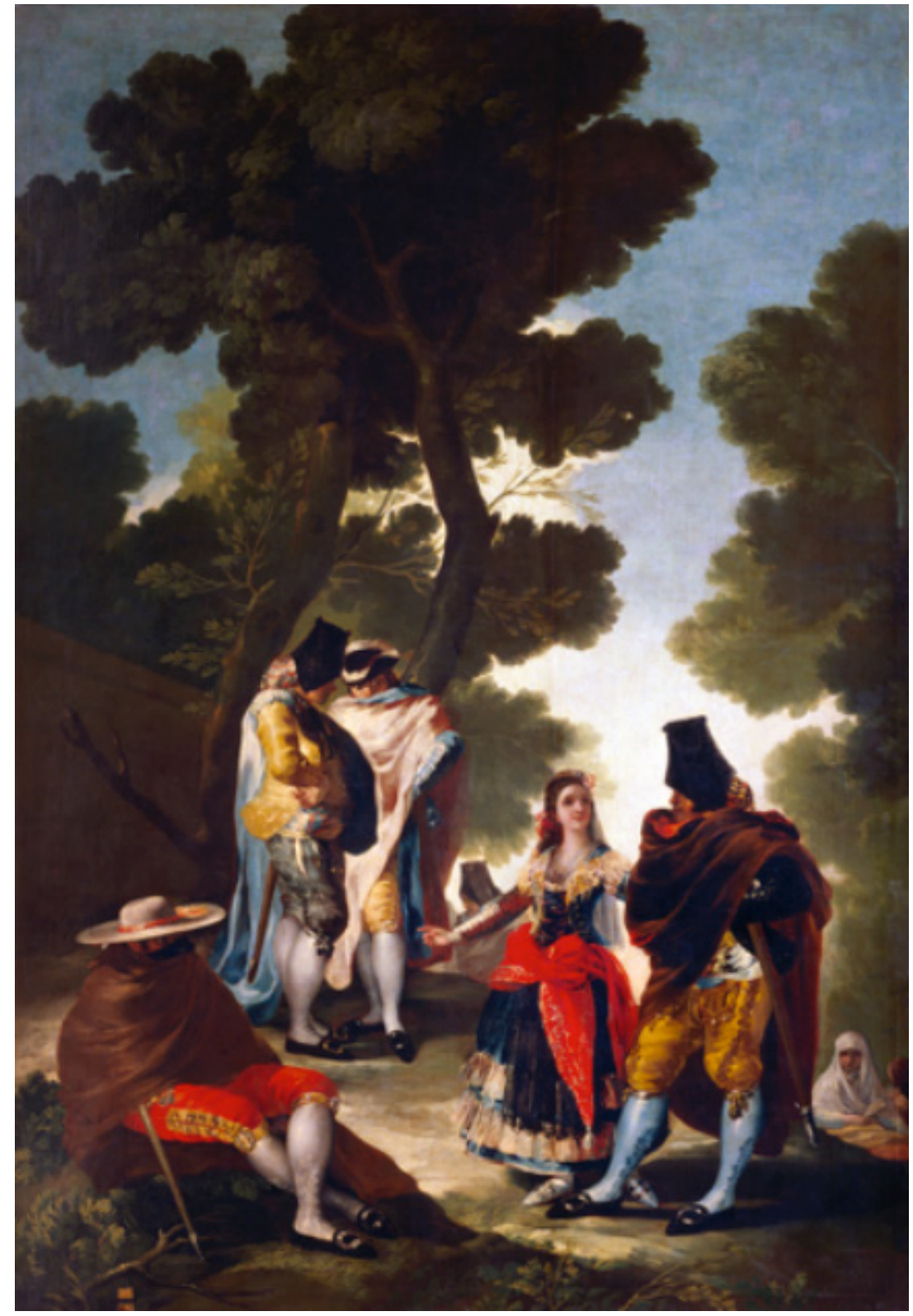

Figura 16

Francisco de Goya, Paseo por Andalucía o La maja y los embozados, 1777. Museo del Prado. 


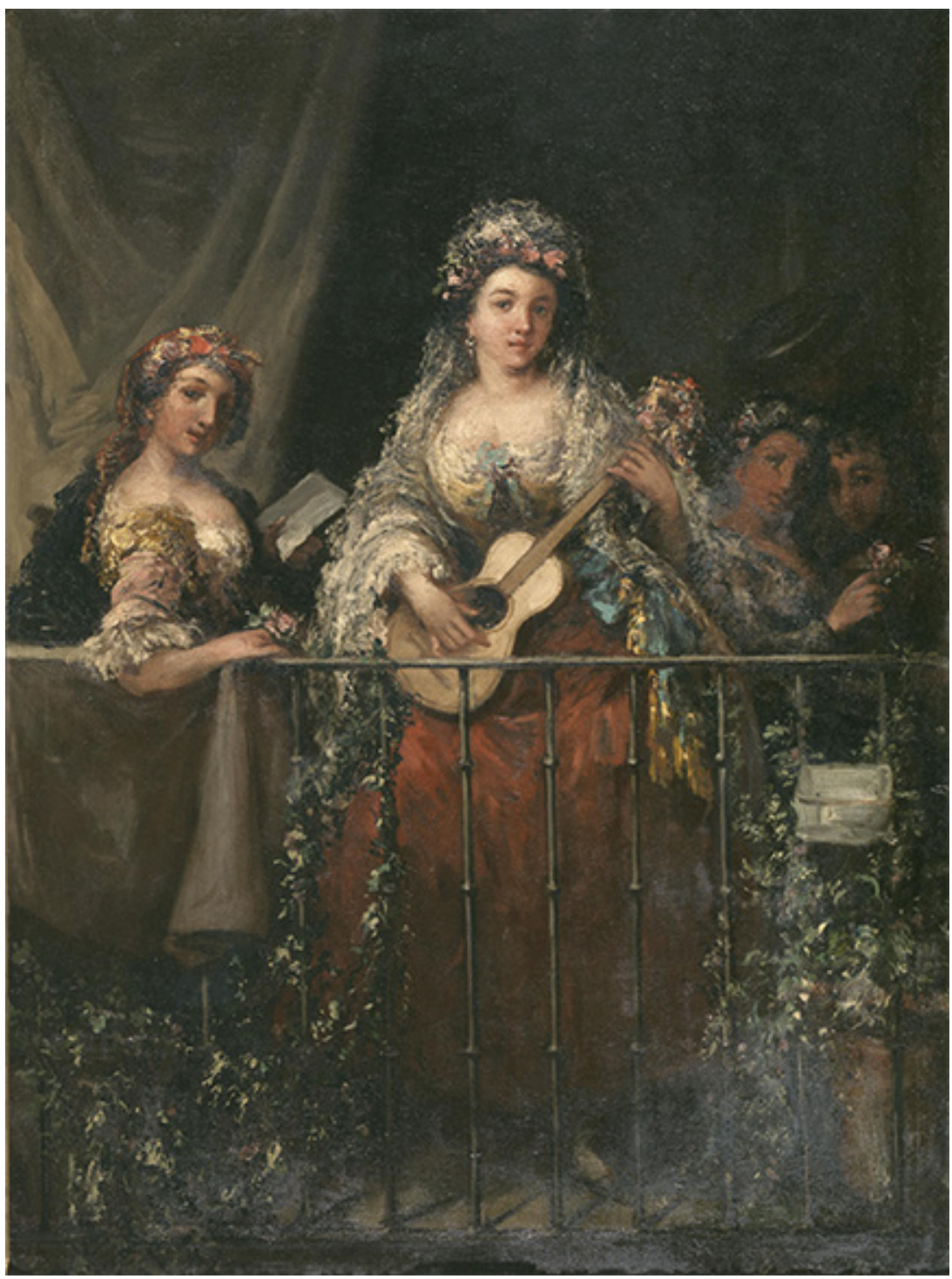

Figura 17

Eugenio Lucas Velázquez, Majas al balcón, 1862, Museo del Prado. 


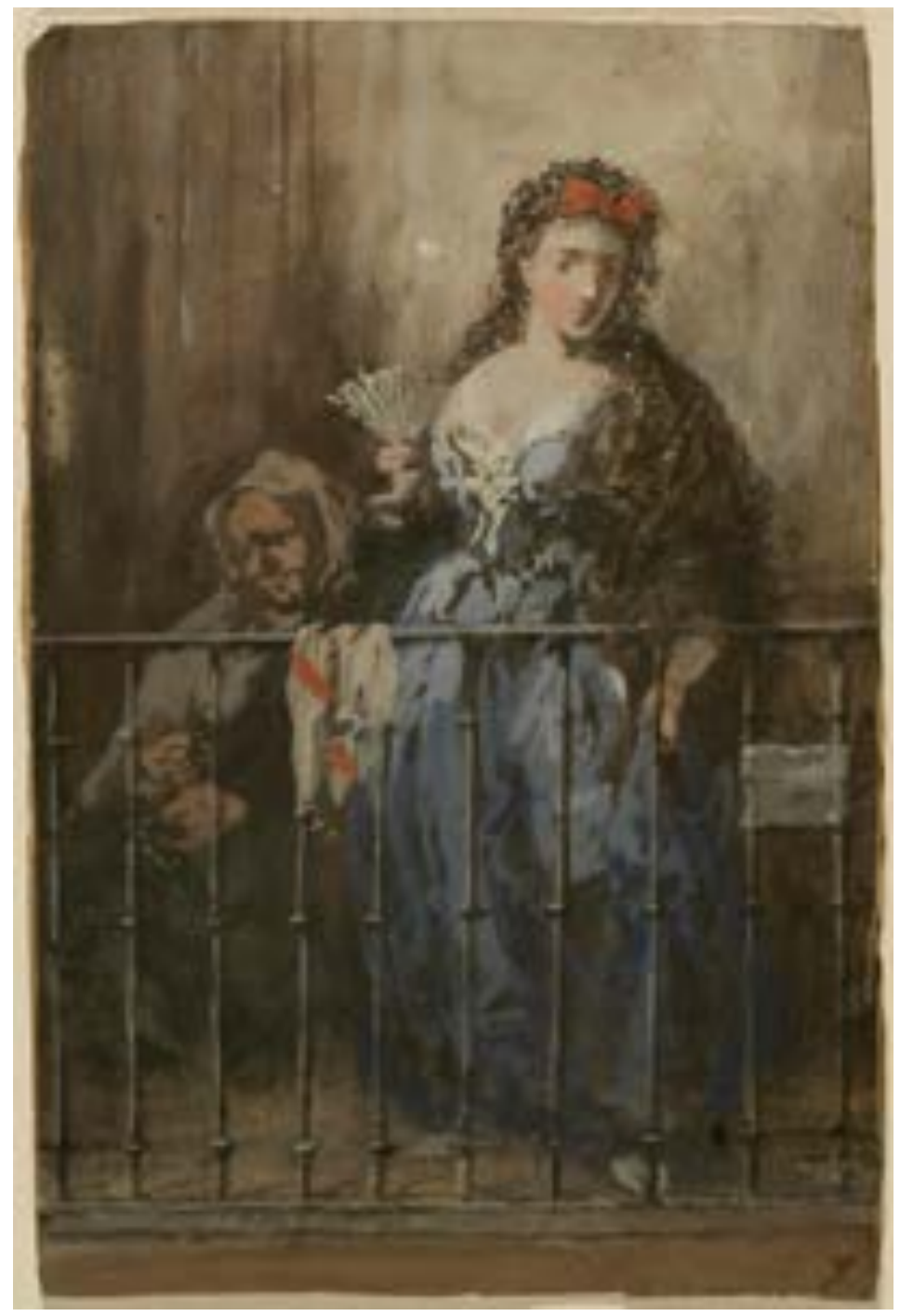

Figura 18

Eugenio Lucas Velázquez, Maja y Celestina en el balcón, A2146, 1847. Por cortesía de la Hispanic Society of America, NY. 


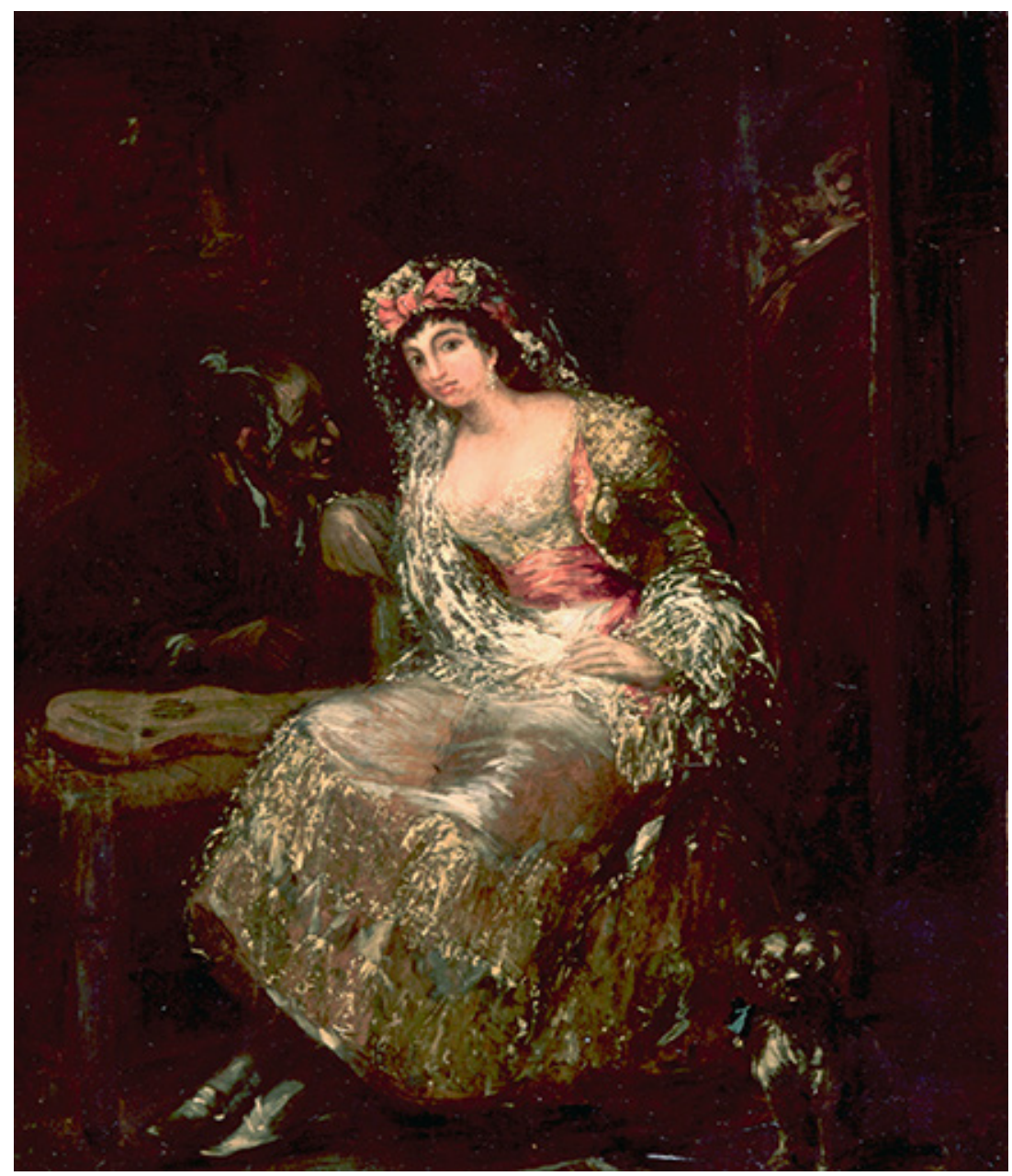

Figura 19

La Maja de Lucas Velázquez, Eugenio. № de inventario 11563.

(C) Museo Lázaro Galdiano. Madrid 


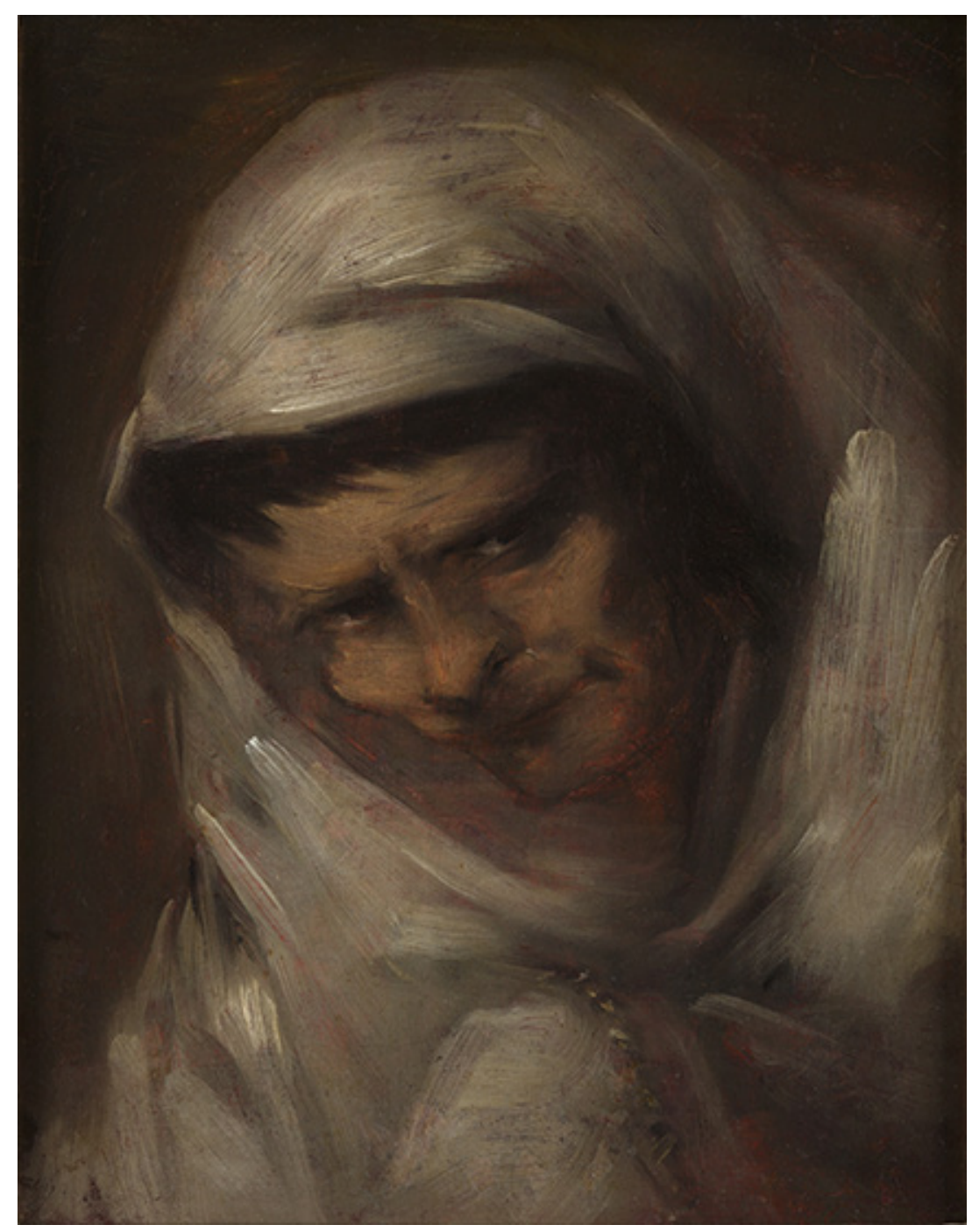

Figura 20

Estudio de cabeza de Lucas Velázquez, Eugenio. No de inventario 12093.

(C) Museo Lázaro Galdiano. Madrid 


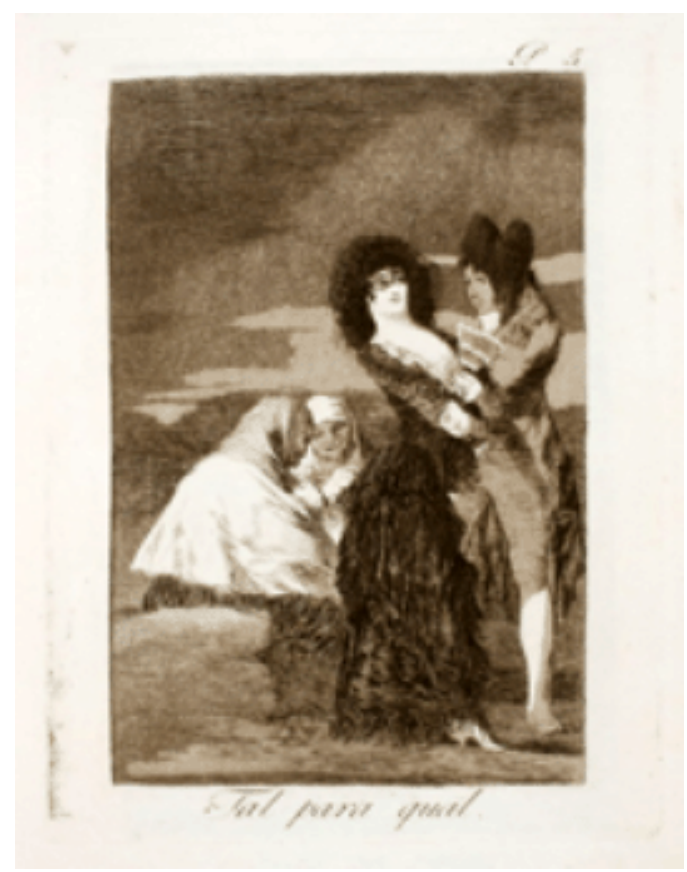

Figura 21

Francisco de Goya, Capricho 5, Tal para cual, 1797-99. Museo del Prado. 


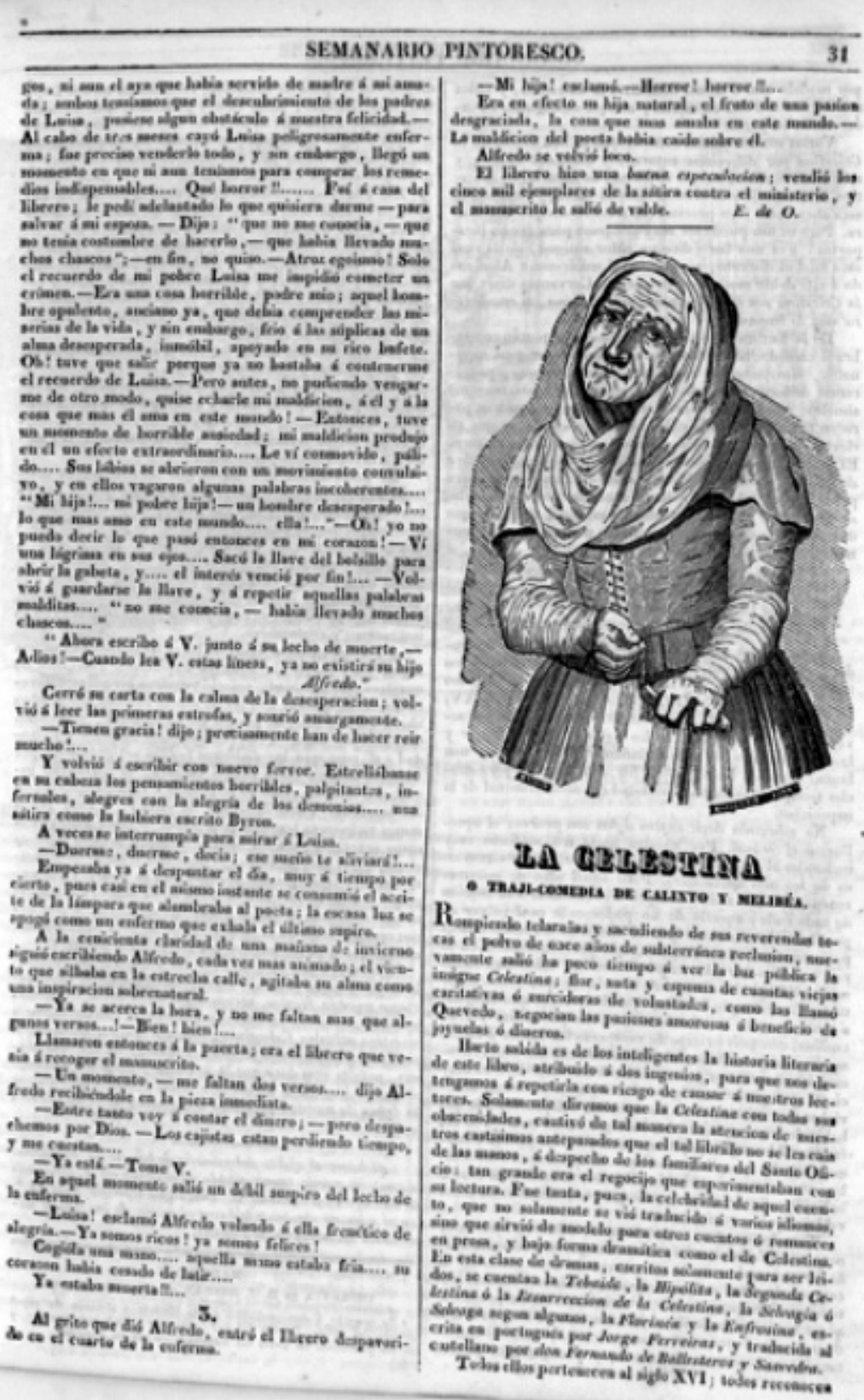

Figura 22

Dib. Madrid y grab. Marquelain. La Celestina.

El Semanario Pintoresco Español. 17 abril 1836. 


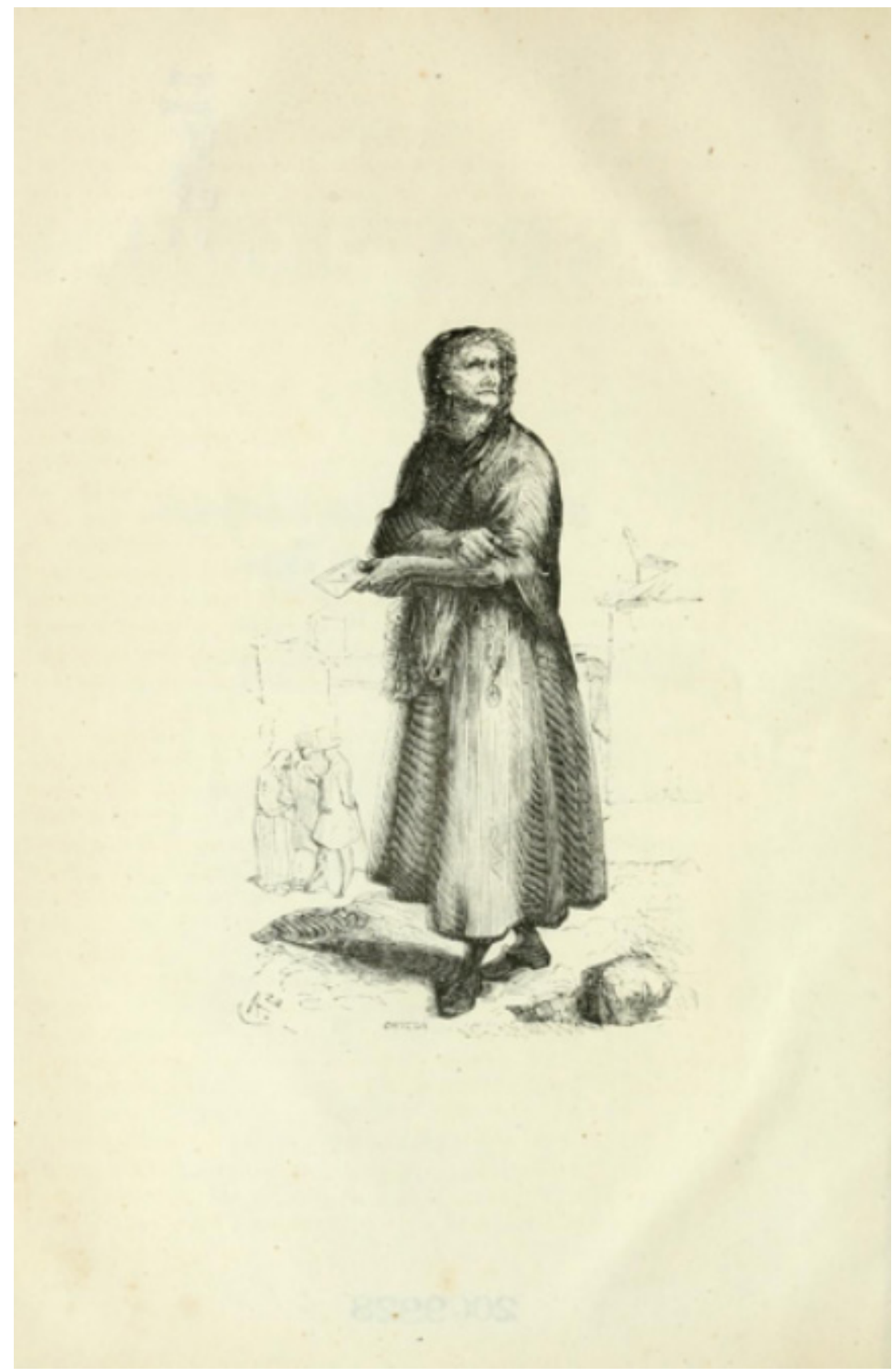

Figura 23

Dib. Leonardo Alenza y Nieto y grab. Ortega. La Celestina. Españoles pintados por sí mismos 1844: 2, frontispicio. 



\section{Schmidt, Rachel, "Celestinas y majas en las obras de Goya, Alenza y Lucas Fernández», Celestinesca 39 (2015), pp. 275-328.}

\section{RESUMEN}

Este artículo examina el desarrollo de dos tendencias iconográficas de las imágenes de la Celestina y la maja en el arte del siglo XIX, ambas establecidas por Goya: la satírica, que a menudo se expresa en medios impresos y que muestra la prostitución como comercio entre seres humanos, conectándola a otros fenómenos sociales, como el matrimonio forzado y los pordioseros; y la sentimental o pintoresca, que a menudo usa el medio pictórico para visiones idealizadas o sensuales de la maja. Leonardo Alenza y Nieto (1807-1845) desarrolla la mirada crítica que Goya posa sobre la prostitución al incorporar figuras masculinas marginales en sus cuadros, retratando las relaciones entre las prostitutas, sus clientes, los pordioseros e incluso la prostitución masculina. Eugenio Lucas Velázquez (1817-1870) pintó durante un periodo en el que la prostitución estaba legalizada y bajo vigilancia médica al ejercerse en burdeles controlados por el estado. Este pintor se aleja de la tradición sentimental para presentar a las majas como víctimas de celestinas bestializadas o como meras figuras folclóricas atractivas.

Palabras ClaVE: Celestina, Goya, Leonardo Alenza y Nieto, Eugenio Lucas Velázquez, pintura, prostitución, maja, alcahueta.

\section{ABSTRACT}

This article examines the development of two iconographic streams of Celestina and maja imagery in nineteenth-century art, both established by Goya: the satirical, which is often expressed through the medium of print and highlights prostitution as commercial trafficking, and links it to other social phenomena such as forced marriage and vagrancy; and the sentimental or picturesque, which is often expressed through paint media and presents an idealized or sensual view of the maja. Leonardo Alenza y Nieto (1807-1845) develops Goya's critical viewpoint on prostitution by incorporating marginal male figures into the imagery, thus bringing into the frame relations between female prostitutes, clients, beggars and even male prostitutes. Eugenio Lucas Velázquez (1817-1870), painting during the period of legalized prostitution in which the sex trade was moved into medically and state controlled brothels, works out of the sentimentalized tradition, depicting the majas as victims of now bestialized celestinas or as merely attractive folkloric figures.

KEY WORDS: Celestina, Goya, Leonardo Alenza y Nieto, Eugenio Lucas Velázquez, painting, prostitution, maja, procuress.

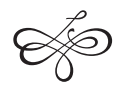

